\title{
4
}

\section{Process Intensification of Steam Reforming for Hydrogen Production}

\author{
Feng Wang1, Guoqiang Wang² and Jing Zhou ${ }^{2}$ \\ ${ }^{1}$ Key Laboratory of Low-grade Energy Utilization Technologies and Systems \\ (Chongqing University), Ministry of Education, Chongqing, \\ ${ }^{2}$ College of Power Engineering, Chongqing University, Chongqing, \\ PR China
}

\section{Introduction}

Hydrogen is considered to be an efficient, clean and environmental, viable energy carrier in the $21^{\text {st }}$ century [1]. Generally, there are many ways to produce hydrogen from both fossil fuels and renewable energy such as solar, wind, geothermal energy and so on $[2,3]$. Yet it is a realistic and practicable method for hydrogen production through hydrocarbon fuel reforming in the near future [7]. In the three types of fuel reforming technologies, namely steam, partial oxidation, auto-thermal reforming, steam reforming has the advantages of low reaction temperature, low $\mathrm{CO}$ content and high $\mathrm{H}_{2}$ content in the products and that is very favorable for mobile applications such as Proton Exchange Membrane Fuel Cell (PEMFC) [4,5].

However, steam reforming (SR) of hydrocarbon fuels is usually strongly endothermic reaction, the process of SR is often limited by heat and mass transfer in the reactors, so it presents a slow reaction kinetics which is characterized by low dynamic response and cold spot in the reactor catalyst bed [6]. Therefore, study of process intensification and optimization of SR for hydrogen production becomes important for the improvement of the reactor performance by enhancing heat and mass transfer and this can be divided to three classes. One way is to adopt new catalyst materials and additives such as coating catalyst, nanometer particle catalyst and so on to enhance the catalytic reforming reaction process [7]; another way is to reduce size scale of reaction channels in steam reforming reactors, for example, using micro-reactors instead of conventional reactors, which can reduce the heat and mass transport resistance by decreasing the transport distance [8]; in addition, microwave direct heating and membrane separation technology are also used to intensify the strongly endothermic SR process [9].

In this chapter, it is studied and stated that methanol and methane are taken as model hydrocarbon fuels for hydrogen production by steam reforming technology and effective process intensification methods of micro-reactor and coating catalyst. The innovative stainless steel micro-reactors which can be used to adopt both kernel catalyst and coating catalyst was designed and fabricated. A novel catalytic coating fabrication method of cold spray technology was also proposed. Experiments and simulation studies were carried out on methanol steam reforming (MSR) and steam methane reforming (SRM) in the microreactor on kernel and coating catalyst respectively. 


\section{Process intensification of methanol steam reforming by micro-reactor}

\subsection{Experimental}

In order to intensify the transport process of methanol steam reforming for hydrogen production, a stainless steel micro-reactor which performs the functions of preheating, evaporation, superheating and reaction was designed and fabricated as shown in Fig.1. Dimension of the reaction section is $60 \mathrm{~mm} \times 50 \mathrm{~mm} \times 3.5 \mathrm{~mm}$ and the height of it can be regulated according to type of catalyst.

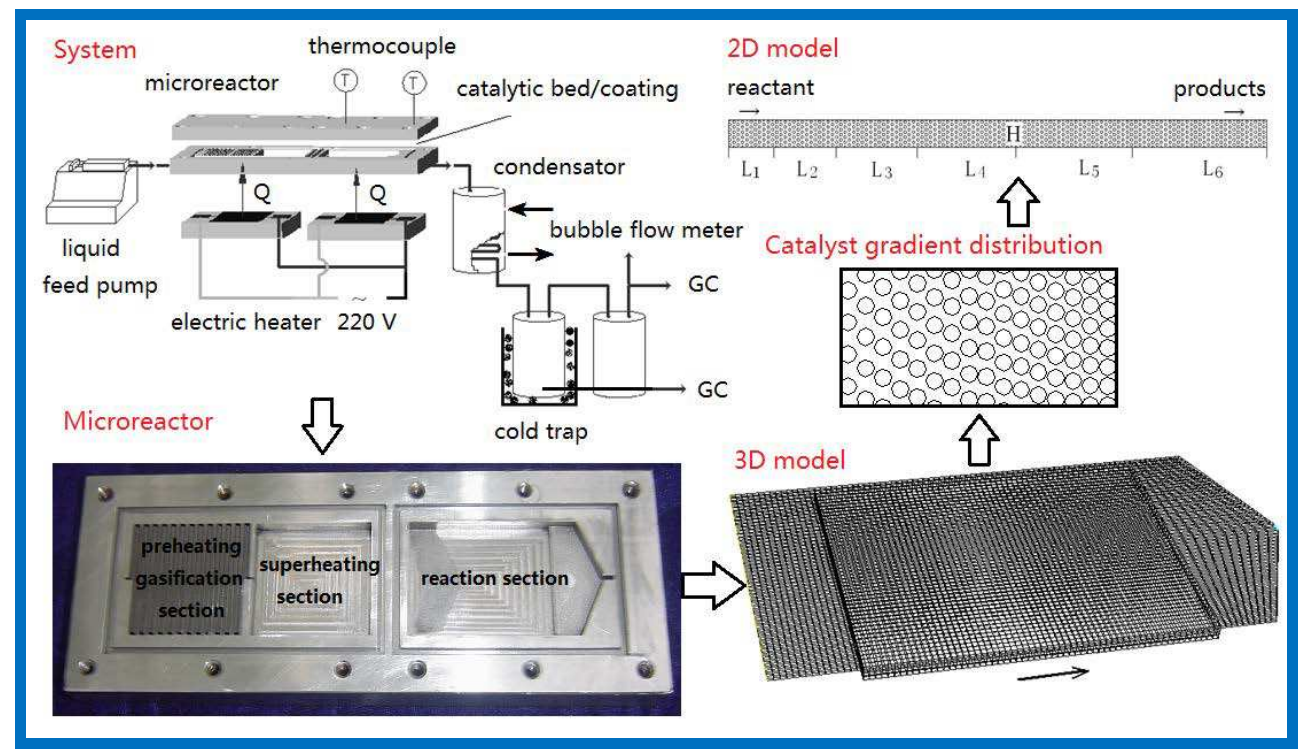

Fig. 1. Methanol steam reforming system, microreactor and the models.

Catalyst used is commercial CB-7 steam reforming catalyst produced by Sichuan Chemical Co. LTD., with the composition of $\mathrm{CuO}, \mathrm{ZnO}, \mathrm{Al}_{2} \mathrm{O}_{3}$ and other additives account for $65 \%$, $8 \%, 8 \%$ and $2 \%$ respectively. The catalyst was grinded into particles with diameters less than $3 \mathrm{~mm}$ and then packed in the reaction section for reactor performance study. As for the catalyst uniform and gradient distribution comparison test, catalyst was grinded to the size of about $1 \mathrm{~mm}$.

Inlet de-ionized water and methanol flow rate was controlled by a syringe pump. The micro-reactor was heated by two electric heaters. Product stream was separated using a cold trap maintained at $0^{\circ} \mathrm{C}$. The flow rate of dry reformed gas was measured by a soap-bubble meter. Composition of gas and un-reacted liquid products was analyzed by a gas chromatograph (GC2000) equipped with a thermal conductivity detector and two packed columns (Poropak-Q for the separation of un-reacted water and methanol, and TDX-01 for the separation of $\mathrm{H}_{2}, \mathrm{CO}_{2}$ and $\mathrm{CO}$ ). Blank run conducted on the empty micro-reactor did not show any detectable methanol conversion. Before the experiment, $\mathrm{N}_{2}$ gas was filled into the system at a flow rate of $30 \mathrm{ml} / \mathrm{min}$ to discharge the air in it and then switched to $\mathrm{H}_{2}-\mathrm{N}_{2}$ $\left(\mathrm{H}_{2} 3 \mathrm{Vol} . \%\right)$ at a flow rate of $40 \mathrm{ml} / \mathrm{min}$ in order to carry out catalyst temperature programmed reduction for 13 hours. 
Effects of reaction temperature, water and methanol molar ratio, liquid space velocity on the reactor outlet parameters such as conversion, selectivity and hydrogen concentration were studied through experiments.

\subsection{Numerical simulation}

A three dimensional physical model of the reaction section was established for simulating reactor performance as shown in Fig.1. Temperature distribution along the flow direction was studied and the MSR kinetic model was obtained by data fitting. In order to study effects of gradient distributed catalyst activity on the transport process in MSR for hydrogen production, a two dimensional physical model of the reaction section was also established. Along the flow direction, reaction section was divided into six segments of different length according to catalyst activity. Catalyst activity was represented by exponential factor $k_{0}$ in kinetic equation. In contrast, uniformly distributed catalyst model was also studied with its $k_{0}$ equaled to the middle activity of the catalyst.

Methanol steam reforming kinetics which includes steam reforming of methanol (SR) and decomposed of methanol (DE) reactions was obtained by data fitting according to the experiment results, and was coupled to the general finite reaction rate model in CFD software of FLUENT3.2.

$$
\begin{gathered}
r_{S R}=4971000 T^{3.0257} \exp \left(-\frac{99.937}{R T}\right) C_{1}^{1.6261} C_{2}^{1.3396}\left(1-\frac{C_{5} C_{3}^{3}}{K_{S R, C} C_{1} C_{2}}\right) \\
r_{D E}=207600 T^{1.1274} \exp \left(-\frac{121.571}{R T}\right) C_{1}^{1.1274}\left(1-\frac{C_{4} C_{3}^{2}}{K_{D E, C} C_{1}}\right)
\end{gathered}
$$

In this study, MSR was treated as homogeneous reaction and the heat and mass differences between the catalyst and the reactants were neglected. Gas mixture was regarded as incompressible ideal gases. Flow in the reaction section was assumed laminar and steady flow. Gravity of the gas and the radiation heat transfer were also neglected. Based on the above assumptions, partial differential governing equations for incompressible flow of ideal gas, heat and mass transfer inside reaction region in the Cartesian coordinate system were written as follows.

Mass:

$$
\frac{\partial\left(\rho V_{j}\right)}{\partial x_{j}}=0
$$

Component:

$$
\rho V_{j} \frac{\partial Y_{S}}{\partial x_{j}}=\frac{\partial}{\partial x_{j}}\left(\rho D \frac{\partial Y_{S}}{\partial x_{j}}\right)+R_{S}
$$

Momentum:

$$
\frac{\partial\left(\rho V_{j} V_{i}\right)}{\partial x_{j}}=-\frac{\partial p}{\partial x_{i}}+\frac{\partial}{\partial x_{j}}\left[\mu\left(\frac{\partial V_{i}}{\partial x_{j}}+\frac{\partial V_{j}}{\partial x_{i}}\right)\right]
$$


Energy:

$$
-\frac{\partial}{\partial x_{j}}\left(\lambda \frac{\partial T}{\partial x_{j}}\right)=\frac{\partial}{x_{j}}\left(\sum \rho D \frac{\partial Y_{S}}{\partial x_{j}} h_{S}\right)+q
$$

Ideal gas equation:

$$
p=\rho R T \sum \frac{Y_{S}}{M_{S}}
$$

Where the letters of $\rho, V, p$ and $T$ are the density, velocity, pressure and temperature of the gas mixture respectively. $Y_{s}$ is mass fraction of gaseous component s; Subscript $s$ represents 1 to 5 for the gaseous component of $\mathrm{CH}_{3} \mathrm{OH}, \mathrm{H}_{2} \mathrm{O}, \mathrm{H}_{2}, \mathrm{CO}_{2}$ and $\mathrm{CO}$ respectively. The coefficients of $D, \mu$ and $\lambda$ are gas mixture's diffusion coefficient, viscosity coefficient and thermal conductivity respectively. They were computed by using the mixing rule of ideal gas. $M_{s}$ is the molar mass of gaseous component s. Letters of $h_{s}$ and $q$ are specific enthalpy of gaseous component $\mathrm{s}$ and reaction heat respectively.

$$
h_{S}=h_{0 S}+\int C_{P S} d T
$$

Where $C_{p s}$ is specific heat at constant pressure of gaseous components.

$$
q=\sum H_{S}^{0} R_{S} M_{S}
$$

Where $H_{S}^{0}$ and $R_{S}$ are standard enthalpy of formation and consumption rate of gaseous component s at reaction region. On micro-reactor inside surface $R_{s}$ is 0 ; while in the reaction section, $R_{s}$ of the component $\mathrm{s}$ is given as the following.

$$
R_{1}=-\left(r_{S R}+r_{D E}\right) M_{1}, R_{2}=-r_{S R} M_{2}, R_{3}=\left(3 r_{S R}+2 r_{D E}\right) M_{3}, R_{4}=r_{S R} M_{4}, R_{5}=r_{D E} M_{4}
$$

Where, $R=8.314 \mathrm{~J}^{\mathrm{mol}}-1 \cdot \mathrm{K}^{-1}$ is the universal gas constant.

\subsection{Results and discussion}

The effects of inlet parameters such as water to methanol mole ratio $W / M$, reaction temperature $T_{r}$, liquid space velocity $W H S V$ on the reactor performance were investigated.

Methanol conversion $\left(\mathrm{X}\left(\mathrm{CH}_{3} \mathrm{OH}\right)\right)$ increased from $76.5 \%$ to $91.2 \%$ when $\mathrm{W} / \mathrm{M}$ increased from 1.0 to 1.5, but the rate of increase was significant at lower $W / M$ then small at higher W/M. Variation of hydrogen yield and mole content of $\mathrm{H}_{2}\left(Y_{\left(\mathrm{H}_{2}\right)}\right)$ in the gas products were similar to that of methanol conversion as shown in Fig.2. However, $\mathrm{CO}$ mole content decreased with the increasing of $W / M$, presenting an inverse variation trend comparing with $\mathrm{X}\left(\mathrm{CH}_{3} \mathrm{OH}\right)$. The reason was that increase of $\mathrm{W} / \mathrm{M}$ enhanced the positive reaction of $\mathrm{SR}$, which resulted in the increase of methanol conversion, hydrogen yield, molar content of $\mathrm{H}_{2}$ and the reduction of $\mathrm{CO}$. In addition, increase of $W / M$ also promoted the reverse of water gas shift (RWGS) reaction that might exist in the reactor, which led to the increase of $\mathrm{H}_{2}$ and reducing of $\mathrm{CO}$. Since $\mathrm{CO}$ is a poison for PEMFC, it should be reduced to the minimum at outlet of micro-reactor as possible. However, latent heat of water is considerable. In MSR reaction, increase of $W / M$ implies increasing of the heat needed for 
preheating, evaporation and superheating of water, and this also affects the reaction temperature. So $W / M$ should not be too high. In this study, $W / M$ of 1.3 is optimal at which the mole content of $\mathrm{CO}$ is only $0.4 \%$.
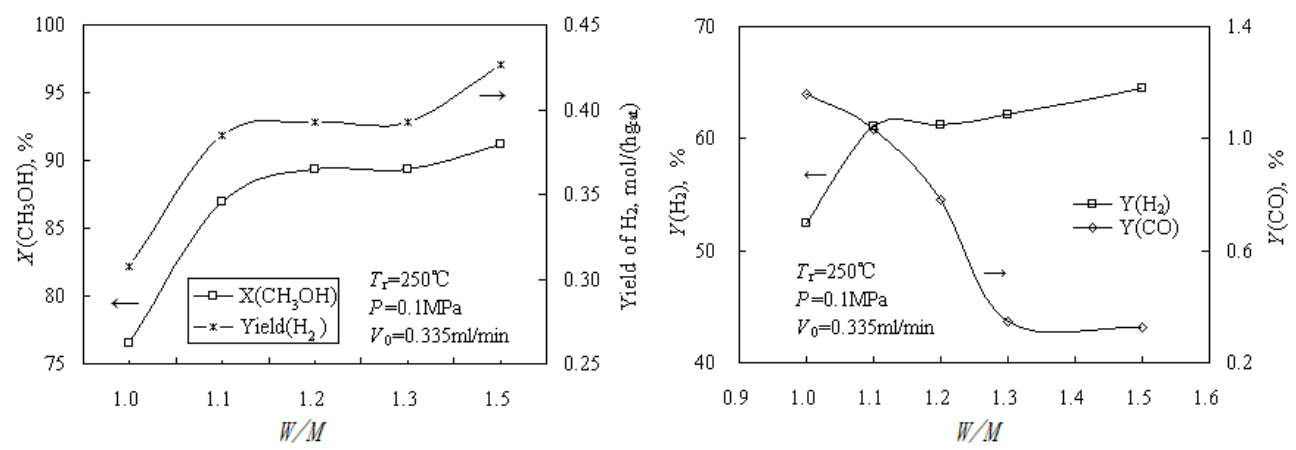

Fig. 2. Effects of $W / M$ on methanol conversion, hydrogen yield, $\mathrm{H}_{2}$ and $\mathrm{CO}$ in the products.

Methanol conversion increased with the rise of reaction temperature and it approached to almost $100 \%$ at $T_{r}=250{ }^{\circ} \mathrm{C}$ and $W H S V=0.2 \mathrm{~h}^{-1}$ as can be seen in Fig.3. Hydrogen yield, mole contents of $\mathrm{H}_{2}$ and $\mathrm{CO}$ also increased with increasing of temperature. Hydrogen yield reached $0.2 \mathrm{~mol} /\left(\mathrm{h} \cdot \mathrm{g}_{\text {cat }}\right)$ under condition of $T_{r}=260{ }^{\circ} \mathrm{C}, W / M=1.3$ and $W G H V=0.2 \mathrm{~h}^{-1}$, which can provide hydrogen for $10.2 \mathrm{~W}$ PEMFC with a hydrogen utilization of $80 \%$ and an fuel cell efficiency of $60 \%$. Owing to the strongly endothermic nature of MSR reaction, increasing of reaction temperature can promote SR reaction and then raise methanol conversion and mole content of $\mathrm{H}_{2}$. However, DE was also a strongly endothermic reaction, so temperature increase can also promote this reaction leading to increase of $\mathrm{CO}$ content although it was less than $1 \%$ in this study. In practical application, the reaction temperature of MSR for hydrogen production has an optimal value, which depends on $W H S V$ and is about $250^{\circ} \mathrm{C}$ in this experiment.
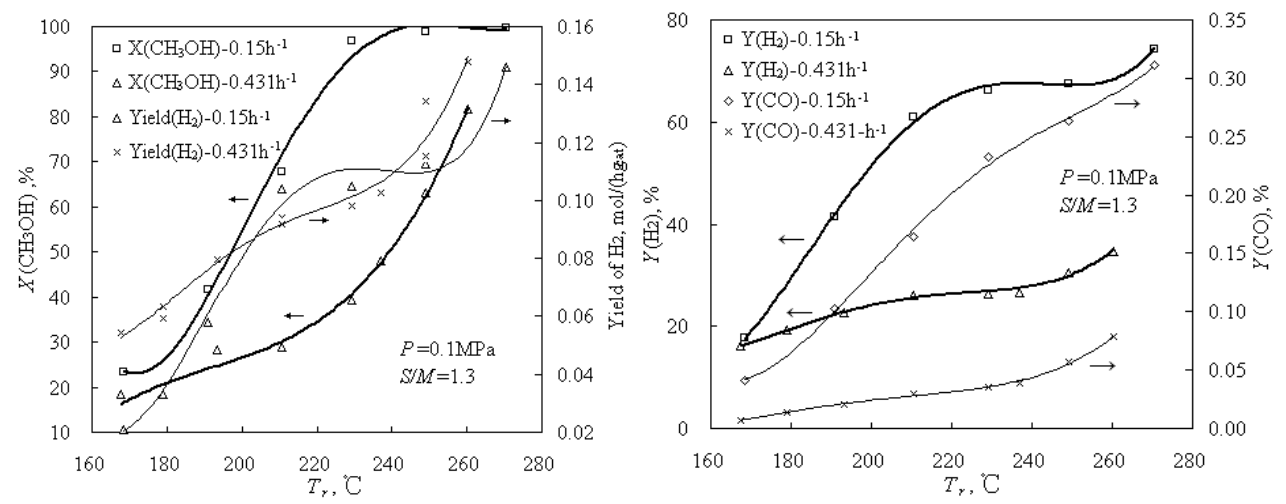

Fig. 3. Effects of temperature on methanol conversion, hydrogen yield, $\mathrm{H}_{2}$ and $\mathrm{CO}$ in the products. 
It can be seen in Fig.4 that, with the increasing of $W H S V$, methanol conversion reduced from $95.7 \%$ to $49.1 \%$; mole content of $\mathrm{H}_{2}$ was also decreased from $70.3 \%$ to $38.3 \%$, whereas $\mathrm{CO}$ rose firstly and then decreased. Hydrogen yield mounted from $0.2 \mathrm{~mol} /\left(\mathrm{h} \cdot \mathrm{g}_{\text {cat }}\right.$.) to about 0.5 $\mathrm{mol} /\left(\mathrm{h} \cdot \mathrm{g}_{\mathrm{cat}}\right)$, then dropped quickly. With the increase of WHSV, residence time of the reactants in the reactor was reduced which resulted in reducing of methanol conversion and $\mathrm{H}_{2}$ mole content. Consequently, in order to increase methanol conversion at higher WHSV, reaction temperature should be increased. However, when WHSV was smaller, $T_{r}$ was the main factor influencing hydrogen production, which promoted positive reaction of $\mathrm{DE}$, and resulted in a gradual increase of CO. When WHSV became larger, it became main factor which influenced the composition of products. And this may promote positive reaction of RWGS and further decreasing CO content. On the other hand, although raise of WHSV caused a reduction of methanol conversion, the methanol flow rate increased which added to hydrogen yield at certain range of $W H S V$. So hydrogen yield rose firstly and decreased afterwards along with increase of WHSV.
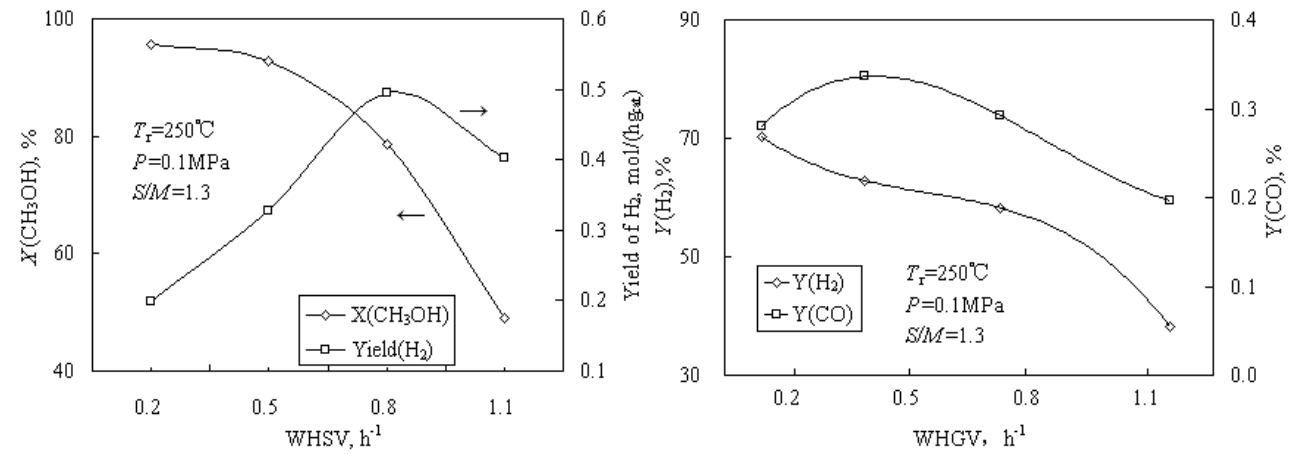

Fig. 4. Effects of liquid space velocity on methanol conversion, hydrogen yield, $\mathrm{H}_{2}$ and $\mathrm{CO}$ content.

Methanol conversion was compared between experiment with 3D simulation as shown in Fig.5. It inferred that numerical model agreed well with experimental results at lower $T_{r}$ but smaller at higher $T_{r}$. This may due to the heating model adopted in simulation as bottom of the reaction area was heated. Whereas in experiment, whole stainless steel micro-reactor including its cover board became a heat source for MSR reaction which led to the increase of methanol conversion. So it was reasonable to use this model to predict the performance of the micro-reactor. In this study, inner surface temperature of the reactor cover was got and compared with simulation as well as reference results. It revealed that a cold spot at the inlet of the reactor of $8.5^{\circ} \mathrm{C}$ and $10^{\circ} \mathrm{C}$ existed from experiment and simulation results. Comparing with reference, it was much smaller due to reduction of reactor size from convention to micro-scale although reaction temperature was higher [10]. In the experiment of methanol steam reforming, catalyst particles were moving from forepart to the back of the reactor due to washing of catalyst bed by reactants, and this resulted in the distribution of catalyst of sparse to dense along the reactor. The cold spot temperature difference may also become smaller than that in the simulation. 

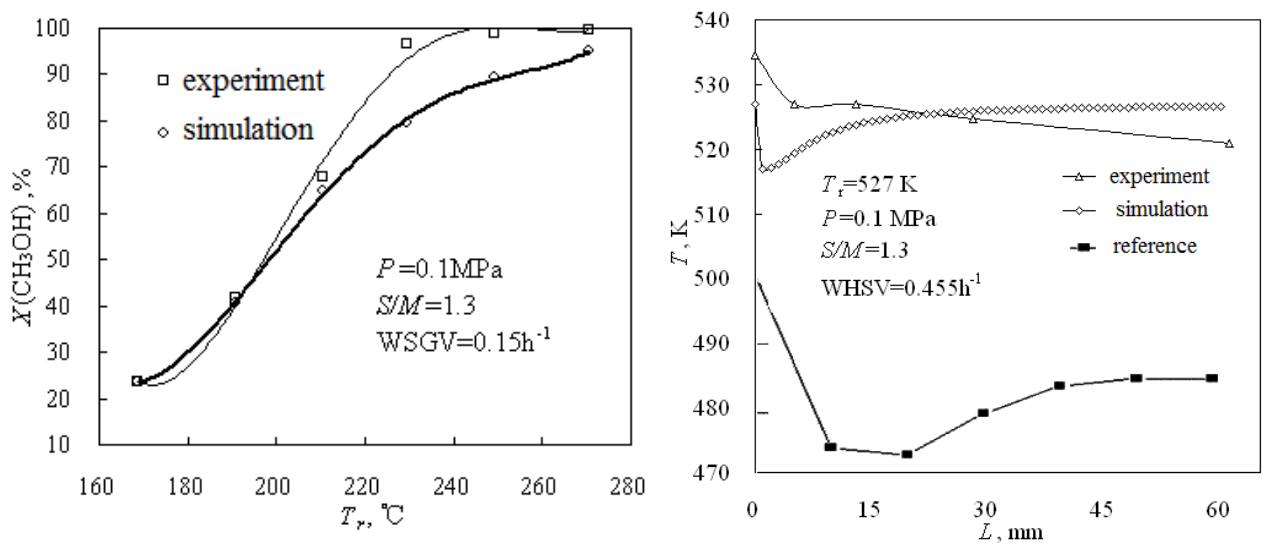

Fig. 5. Experiment, numerical and literature comparisons of methanol conversion and temperature distribution in the reactor.

From the above comparison results of experiment and simulation, it indicated that through controlling of catalytic activity in the reactor, the temperature distribution can be optimized and the cold spot effect can be minimized. So in this section gradient distributed catalyst bed was designed and simulated in 2D model. As can be seen in Fig.6, although the number of cold spot increased under gradient distributed catalyst bed compared with the uniform distributed situation, the maximum cold spot temperature difference decreased about $10 \mathrm{~K}$. Furthermore, as heat and mass transport resistances between the catalyst material and the reactants were neglected in 2D and 3D simulation, it can be inferred that this gradient distribution of catalyst will be more beneficial under transport limitation conditions.
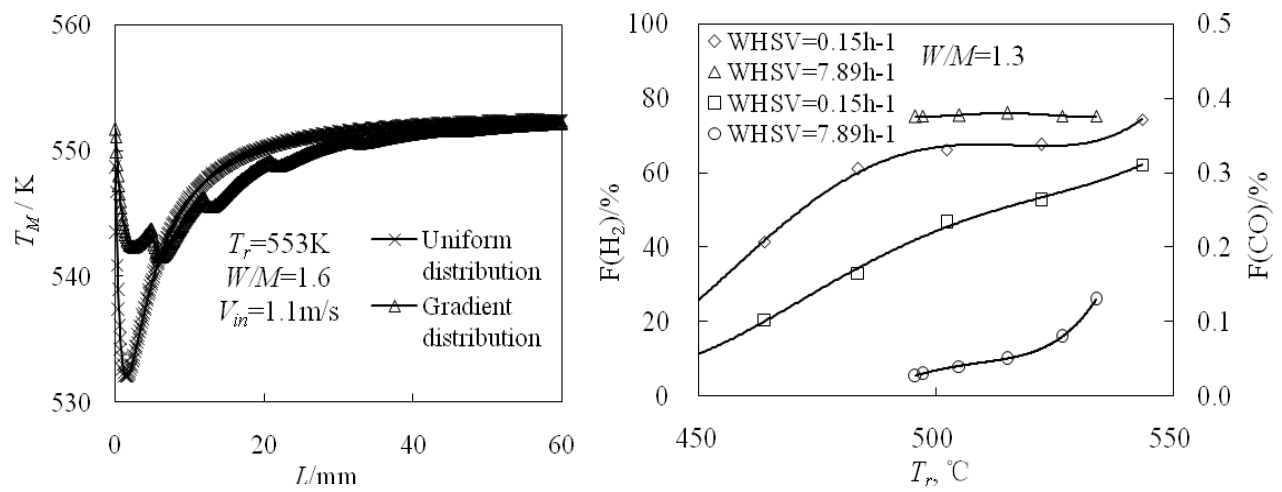

Fig. 6. Comparison of temperature along the centerline of reaction section, outlet $\mathrm{H}_{2}$ and $\mathrm{CO}$ contents under uniform and gradient catalyst distribution conditions.

Although $W / M$ of $7.89 \mathrm{~h}^{-1}$ at catalyst gradient distribution is far greater than $0.15 \mathrm{~h}^{-1}$ at uniform distribution, outlet hydrogen content nearly approached theoretical hydrogen content of $75 \%$, which increased by about $8.5 \%$ compared with catalyst uniform distribution condition; while outlet CO content reduced to less than $0.13 \%$. As MSR reaction is a strongly 
endothermic process, it can be inferred that gradient catalytic activity distribution is able to reduce the cold spot effect significantly and this effect can be applied to any catalytic reaction with strong heat effect. And it will be more useful in large scale catalyst reactors due to the increasing heat and mass resistance in the catalytic bed.

\section{Process intensification of steam reforming by cold sprayed catalytic coating}

\subsection{Experimental}

Except micro-scale reactor adoption, coating catalyst can also be used to reduce heat and mass transfer resistance from the catalyst surface to the main stream. In this section, several kinds of coatings were deposited using the cold spray system developed by Chongqing University for methanol and methane steam reforming. The system includes gas pressure regulators, gas preheater, gas flow meters and spraying gun as shown in Fig.7. The gun consists of a gas
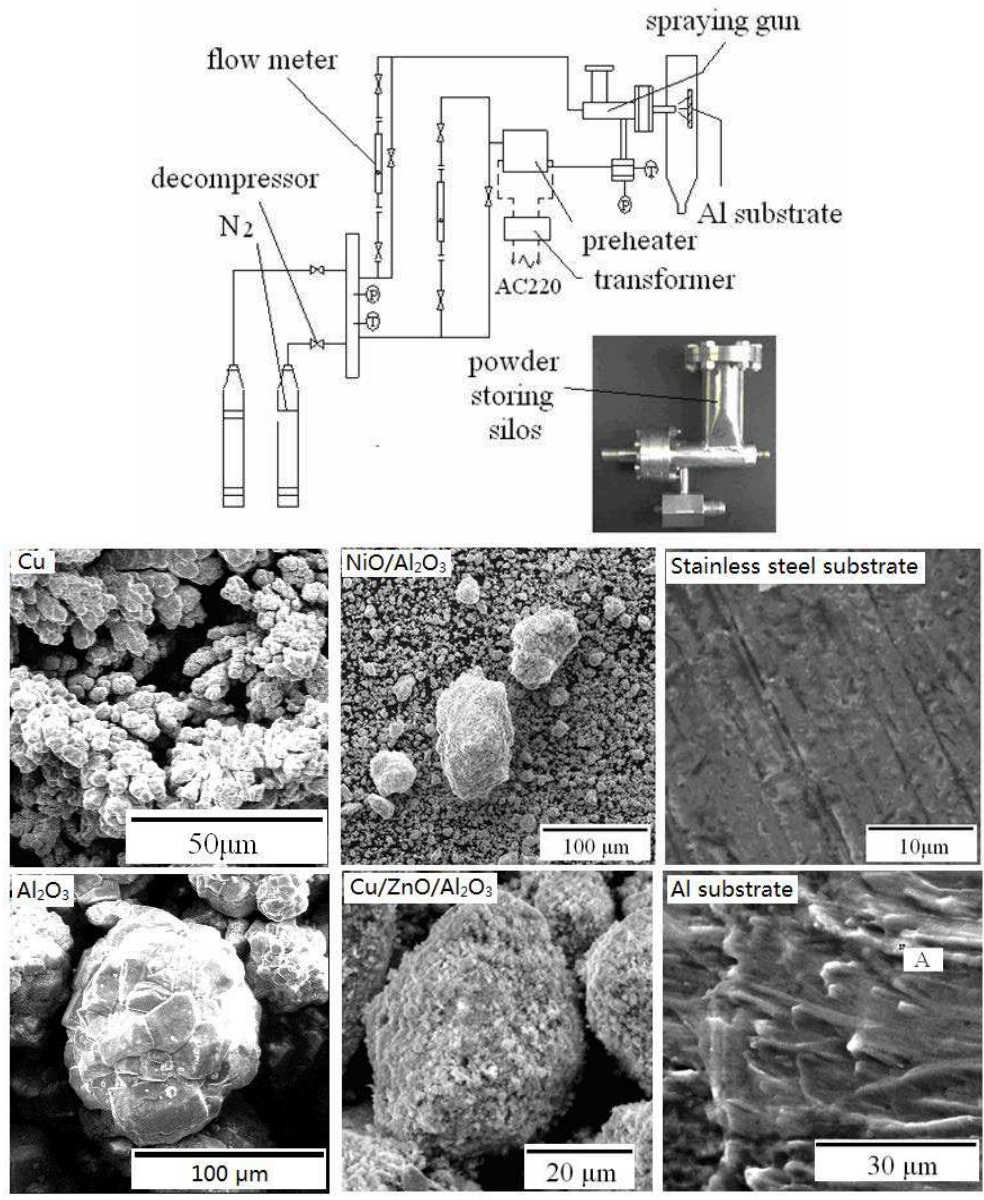

Fig. 7. Schematic of cold spray system, the gun and morphology of different feedstock. 
chamber, a powder storage chamber and a convergent-divergent accelerating nozzle. And nozzle throat diameter is $1.5 \mathrm{~mm}$ with an exit diameter of $2.6 \mathrm{~mm}$. Length from the throat to the exit is $62.6 \mathrm{~mm}$, among which the expansion section is $12.6 \mathrm{~mm}$, the other is straight tube. In this study, nitrogen was used as a driving gas and carrying gas with an inlet pressure of 1.4 and $1.6 \mathrm{MPa}$ for the heating gas and powder carrying gas separately. Heating gas temperature range is $573 \mathrm{~K}$ to $773 \mathrm{~K}$. Stand-off distance of the substrate from nozzle exit is $20 \mathrm{~mm}$. During spraying, the substrate was manipulated by a running gear and traversed at a relative speed of $5 \mathrm{~mm} / \mathrm{s}$ over the substrate.

Four kinds of powders of $\mathrm{Cu}, \mathrm{Cu}-\mathrm{Al}_{2} \mathrm{O}_{3}$ composite, milled commercial $\mathrm{Cu} / \mathrm{ZnO} / \mathrm{Al}_{2} \mathrm{O}_{3}$ for MSR and primary $\mathrm{NiO} / \mathrm{Al}_{2} \mathrm{O}_{3}$ catalyst for SRM with diameters less than $75 \mu \mathrm{m}$ were used as feedstock. Morphology of the powders and substrate of $\mathrm{Al}$ and stainless steel after surface treatment were shown in Fig.7. It can be seen that all the powders are of irregular shape and with different size scale except that of $\mathrm{Al}_{2} \mathrm{O}_{3}$ with spherical morphology. $\mathrm{Cu}$ powder is of arborization morphology, while $\mathrm{NiO} / \mathrm{Al}_{2} \mathrm{O}_{3}$ and $\mathrm{CuO} / \mathrm{ZnO} / \mathrm{Al}_{2} \mathrm{O}_{3}$ catalytic powders are irregular kernel morphology. Before spraying, the substrate was polished by sand paper in order to wipe off the oxide film, and then cleaned by ethanol and deionized water.

The morphology of the feed stock and coating before and after methanol and methane steam reforming was observed using scanning electron microscopy (SEM) (TESCAN VEGAII LMU). And the micro-region element composition was examined by EDX. Phase structure was characterized using X-ray diffraction (XRD) system (D/MAX-3C) with Co Ka1 radiation at $35 \mathrm{kV}$ and $30 \mathrm{~mA}$. Scan speed for $2 \theta$ was $2.5 \%$ min during test.

Experiments of methanol and methane steam reforming for hydrogen production were carried out to examine the cold sprayed $\mathrm{Cu}$-based and Ni-based coating performance at atmosphere pressure.

\subsection{Results and discussion}

Morphology of the cold sprayed coatings before and after steam reforming reaction were shown in Fig.8. Cu-based catalytic coatings were used in methanol steam reforming, whereas Ni-based catalytic coatings were used in methane steam reforming.

It can be seen that the particles are severely deformed in $\mathrm{Cu}$ coating, the arborization morphology of the $\mathrm{Cu}$ powder is disappeared. After MSR reaction, morphology of the coating changes from piled sheets structure to micro-ramify structure, its porosity obviously increases, but carbon deposition is serious. This structure can be caused by repeatedly oxidization and reduction in MSR because when MSR experiment system shuts down, oxygen in the air may be in touch with the coating, and hydrogen in the reformed gas is able to play a reduction effect. It was also found that copper coating can recover its activity by contacting with oxygen, so the loss of catalytic activity was due to the gradual exhaustion of the surface oxygen on the copper surface. So it was concluded that the active site of $\mathrm{Cu}$ based catalyst for MSR may be copper oxide species, either $\mathrm{Cu}^{+}$or $\mathrm{Cu}^{2+}$.

While in the $\mathrm{Cu}-\mathrm{Al}_{2} \mathrm{O}_{3}$ coating, copper powders are not severely deformed. The main reason is that the properties of $\mathrm{Cu}$ and $\mathrm{Al}_{2} \mathrm{O}_{3}$ powders are so different. This results in the different flying speed of the particles which leads to the deposition efficiency and micro-region component in the coating to be ill-proportioned. Another reason is that single $\mathrm{Al}_{2} \mathrm{O}_{3}$ powder is aggregation of smaller kernels, in collision with the $\mathrm{Al}$ substrate, $\mathrm{Al}_{2} \mathrm{O}_{3}$ powders are shattered to smaller pieces and this cracking makes the situation even worse. This effect is more obvious in the coating after MSR for small pieces of $\mathrm{Al}_{2} \mathrm{O}_{3}$ with white present region. MSR on the $\mathrm{Cu}-\mathrm{Al}_{2} \mathrm{O}_{3}$ coating shows that it is more stable than the copper coating. Probable 


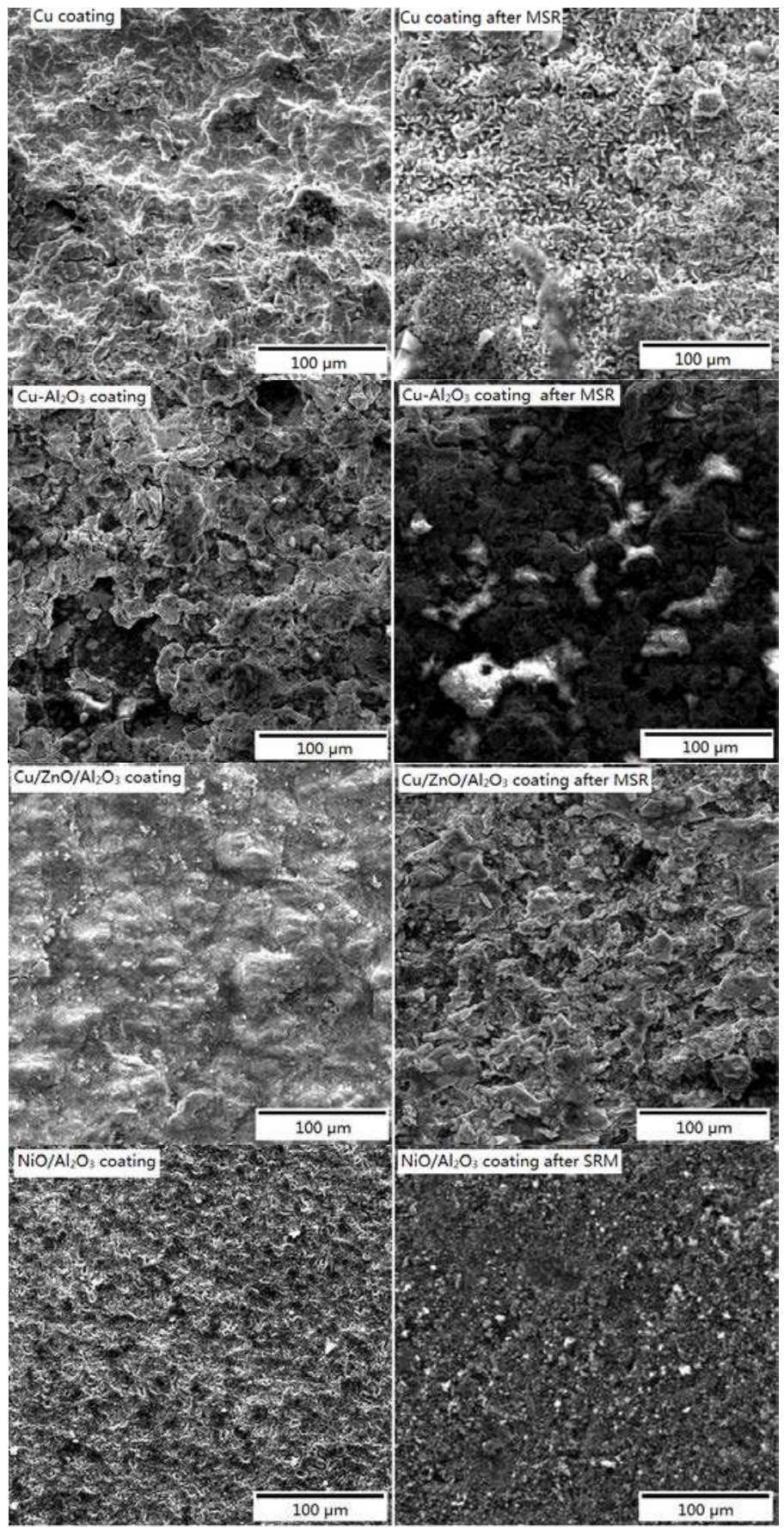

Fig. 8. Morphology of the cold sprayed coatings before and after steam reforming. 
reason is that the smashed $\mathrm{Al}_{2} \mathrm{O}_{3}$ pieces prevent the active $\mathrm{Cu}$ in the coating from sintering. What's more, $\mathrm{Al}_{2} \mathrm{O}_{3}$ component provides and stabilizes the surface oxygen in the $\mathrm{Cu}-\mathrm{Al}_{2} \mathrm{O}_{3}$ coating. In this study it appears that the predominant mechanism for bonding was mechanical interlocking, especially for the $\mathrm{Cu}-\mathrm{Al}_{2} \mathrm{O}_{3}$ composite and $\mathrm{CuO} / \mathrm{ZnO} / \mathrm{Al}_{2} \mathrm{O}_{3}$ catalytic coating.

Cold sprayed $\mathrm{CuO} / \mathrm{ZnO} / \mathrm{Al}_{2} \mathrm{O}_{3}$ catalytic coating appears to not as porous as the powder in the feedstock. This is due to that binder in the catalyst goes soft in the spraying and colliding process and re-solidifies gradually. After methanol steam reforming, it presents a loosen structure morphology and this is formed by the deposited powder's washing away by the reacting fluid. From the above analysis it can be included that the deposition characteristic of the oxide aggregation feedstock is noticeably different from that of the pure metal powder. The bonding mainly belongs to mechanical bite and physical bonding.

Composition analysis showed that after surface treatment $\mathrm{Al}$ substrate contains mainly $\mathrm{Al}$ element, and $\mathrm{O}$ element in the surface is less than $5.82 \%$. As for the $\mathrm{Cu}-\mathrm{Al}_{2} \mathrm{O}_{3}$ composite coating, $\mathrm{O}$ and $\mathrm{Al}$ elements increase in the coating after reaction, correspondingly $\mathrm{Cu}$ element decreases. In the original feedstock of the composite coating, $\mathrm{Cu} / \mathrm{Al}$ ratio (wt. \%) is about 6.48, whereas in the deposit, $\mathrm{Cu} / \mathrm{Al}$ ratio decreases dramatically. Before reaction this ratio is 3, after reaction, it decreases to 1.5 , it seems that $\mathrm{Cu}$ powders are "missing" in the cold spray process. This may be strange because it is known that $\mathrm{Cu}$ powder is much more prone to deform than $\mathrm{Al}_{2} \mathrm{O}_{3}$ powder. The probable reason may lies in the morphology of the powders, although the $\mathrm{Cu}$ powder with irregular morphology presents a higher in-flight particle velocity than $\mathrm{Al}_{2} \mathrm{O}_{3}$ with spherical morphology with same size, the deposition efficiency of $\mathrm{Cu}$ is lower than $\mathrm{Al}_{2} \mathrm{O}_{3}$ powder. Content of component in the coating and feedstock of the $\mathrm{CuO} / \mathrm{ZnO} / \mathrm{Al}_{2} \mathrm{O}_{3}$ is approximately the same except that $\mathrm{O}$ content in the coating after reaction decreases, while Al increases. Possible reason is that when the small pieces in the coating are not strongly integrated into the substrate and washed off by reacting fluid, the $\mathrm{Al}$ phase in the substrate goes into the EDX analysis. And this is just the proof that $\mathrm{CuO} / \mathrm{ZnO} / \mathrm{Al}_{2} \mathrm{O}_{3}$ coating fabricated by cold spray is very thin, may be monolayer or at most 2 to 3 layers. Therefore, thickness of the coating is determined by the dimension of feed powders and this provides a kind of nanometer catalytic coating fabrication method. The reason that thickness of $\mathrm{CuO} / \mathrm{ZnO} / \mathrm{Al}_{2} \mathrm{O}_{3}$ coating cannot be further increased is that when a first monolayer is formed on the substrate, $\mathrm{CuO} / \mathrm{ZnO} / \mathrm{Al}_{2} \mathrm{O}_{3}$ powders arrive at the monolayer surface soon after has to collide with non-deformable $\mathrm{CuO} / \mathrm{ZnO} / \mathrm{Al}_{2} \mathrm{O}_{3}$ coating. Here the main process is powder's subsequent tamping effect and this effect results in the smashing of the catalytic powder. Deposition efficiency decreases greatly.

MSR was carried out on the three types of Cu-based coating. Results show that, at the reaction temperature of $190^{\circ} \mathrm{C}$ to $200^{\circ} \mathrm{C}, \mathrm{H}_{2}$ concentration increases from $28.6 \%$ to $42.6 \%$, and reaches $57.4 \%$ on $\mathrm{Cu}-\mathrm{Al}_{2} \mathrm{O}_{3}$ coating. $\mathrm{H}_{2}$ content in the reformed products reaches $74.9 \%$ at $250^{\circ} \mathrm{C}$ on the $\mathrm{Cu}$ coating, but the activity loses very quickly. While at the condition of inlet temperature $265^{\circ} \mathrm{C}$, water and methanol molar ratio 1.3 , fluid flow rate $0.54 \mathrm{ml} / \mathrm{min}, \mathrm{H}_{2}$ content in the products for $\mathrm{CuO} / \mathrm{ZnO} / \mathrm{Al}_{2} \mathrm{O}_{3}$ catalytic coating reaches $52.31 \%$, whereas $\mathrm{CO}$ content is only $0.60 \%$. Through the weighing of the catalytic plate before and after cold spray process, we get the weight of the catalytic coating of merely $100 \mathrm{mg}$, and thus the liquid space velocity is equal to $5.10 \mathrm{~mol} /(\mathrm{g} \mathrm{h})$ (or $162 \mathrm{~h}^{-1}$ ). Compared to the fixed bed kernels in the reaction section of the reactor, the activity of the cold sprayed $\mathrm{CuO} / \mathrm{ZnO} / \mathrm{Al}_{2} \mathrm{O}_{3}$ catalytic coating is much higher [11]. One possible reason may be that heat and mass transfer is fast on the $\mathrm{CuO} / \mathrm{ZnO} / \mathrm{Al}_{2} \mathrm{O}_{3}$ catalytic coating than the conventional fixed bed catalyst, especially in micro-reactors. 
Morphology of the cold sprayed $\mathrm{NiO} / \mathrm{Al}_{2} \mathrm{O}_{3}$ coating before and after SRM is also shown in Fig.8. It presented a rough surface morphology. Granule appearance of staring $\mathrm{NiO} / \mathrm{Al}_{2} \mathrm{O}_{3}$ powders disappeared in the coating, so it could be inferred that the particles were severely deformed by high speed impact with the stainless steel substrate. Detailed examination of the surface morphology clearly showed that surface structure of the cold sprayed deposit was somewhat different to the powder. Its porosity seemed higher than the feedstock, and this is favorable for catalytic surface reactions because area of the coating surface increased at same volume catalyst. Since $\mathrm{NiO} / \mathrm{Al}_{2} \mathrm{O}_{3}$ powder was aggregation of smaller kernels with different size scale, and it is not easy to deform when colliding with substrate, $\mathrm{NiO} / \mathrm{Al}_{2} \mathrm{O}_{3}$ powders were shattered to smaller pieces due to the high shear rate that occurred when a high velocity particle was arrested by collision with the substrate surface and/or deposited coating surface. Therefore, it could be concluded that the process of oxide aggregated catalytic coating fabrication by cold spray is not like the metal coating fabrication, smashing of the striking powder takes a main role in the coating formation. In this study it appeared that the predominant mechanism for bonding was mechanical interlocking. Although different size scale powders were used as feedstock, the cold sprayed coatings seemed to have a homogeneous distribution of the powders and consisted of several layers. The reason was that when the brittle $\mathrm{NiO} / \mathrm{Al}_{2} \mathrm{O}_{3}$ powders collided with the substrate and/or the coating previously formed, they smashed into small particles, only the particles in suitable size range reached and kept its velocity above the critical velocity and attained valid deposition. The larger one smashed further and the smaller one was washed away by the high speed gas flow. And this is one of the reasons that the coating could not build up further no matter how many passes the deposition was repeated for. Since the deposition efficiency would be dramatically decreased.

After 100h SRM reaction on stream, SEM images showed the formation process of filamentous carbon on the catalytic coatings, and this is one of the reasons that led to the drop of catalyst coating activity since a portion of the active coating surface was covered by deposited carbon. However, activity of catalyst coating remained stable for a relatively long period of $100 \mathrm{~h}$ in the SRM experiment. In addition, highly dispersed small nickel particles on the cold sprayed catalyst coating were responsible for strong resistance toward carbon deposition in the steam reforming of methane. After 100h SRM reaction, there was no obvious peeling off of the coating, indicating a good bonding between the coating and substrate.

The EDX analysis results showed that Ni content in the cold sprayed coating was higher than the initial catalyst powder, and this could be due to the characteristic of cold spraying process. Since the impact velocity is affected by the spraying material, it will be easier for the powder with higher density to deposit in this situation, so the particles with higher $\mathrm{Ni}$ content had more chance to successfully deposit. After SRM reaction, some of the coating surface was covered by carbon, so Ni content decreased.

Primary steam reforming of methane for hydrogen production was carried out in the temperature range of $845 \mathrm{~K}$ to $995 \mathrm{~K}$, and steam to carbon ratio $(S / C)$ changed from 2.5 to 10.0 , the space velocity ranged from $9.9 \times 10^{4} / \mathrm{h}$ to $3.0 \times 10^{5} / \mathrm{h}$. The results are shown in Fig.9. It can be seen from the data that methane conversion increased with the reaction temperature and decreased with methane space velocity. There was report of $37.4 \%$ conversion of methane at the reaction temperature of $973 \mathrm{~K}$, reactor pressure of $3.0 \mathrm{MPa}$, steam to carbon ratio $(S / C)$ of 2.7 and inlet gas hourly space velocity (GHSV) of $0.2 \times 10^{5} \mathrm{~h}^{-1[7]}$. At relatively lower $\mathrm{S} / \mathrm{C}$ of 2 , much higher GHSV of $1.8 \times 10^{5} \mathrm{~h}^{-1}$ and reaction temperature of $976 \mathrm{~K}$, methane conversion in our study was $8.1 \%$. Although this value was lower than the reference above, but 
considering the nine times higher GHSV, it could be concluded that cold sprayed $\mathrm{NiO} / \mathrm{Al}_{2} \mathrm{O}_{3}$ coating is superior to kernel catalyst in packed bed reactor as its high output. Cold sprayed catalytic coating is excelled catalyst prepared by conventional methods, the fundamental reason lies in the superior bonding of coating with substrate, reduced heat and mass transfer limitation in the reaction.
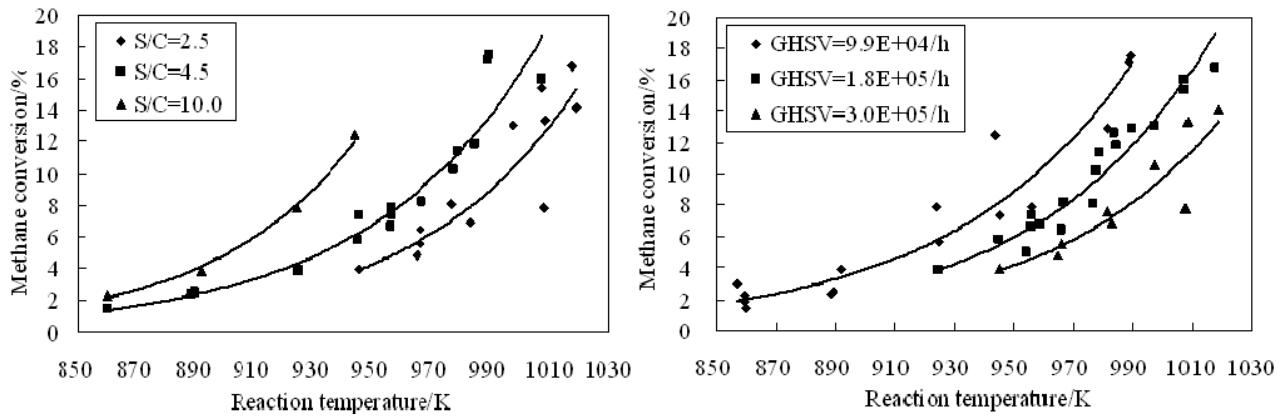

Fig. 9. SRM performance of the cold sprayed coating.

\section{Process intensification by catalytic surface and activity distribution}

\subsection{Simulation method description}

For the further optimization of the transport characters of MSR in the micro-reactor with coating catalyst, effects of catalytic surface distribution, catalytic activity distribution on the micro-reactor performance were investigated by numerical simulation. With the application of general finite reaction rate model in CFD software of FLUENT, 2D simulation of this process was carried out.

Along the flow direction, the inner up and down surface of the micro-channel was divided to 12 equal sections as shown in Fig.10. Every section was named by $u p_{i}$ or down $i=1,2$, $3 \ldots 12$; so the total 24 sections can be selectively combined according to catalytic surface and activity design.
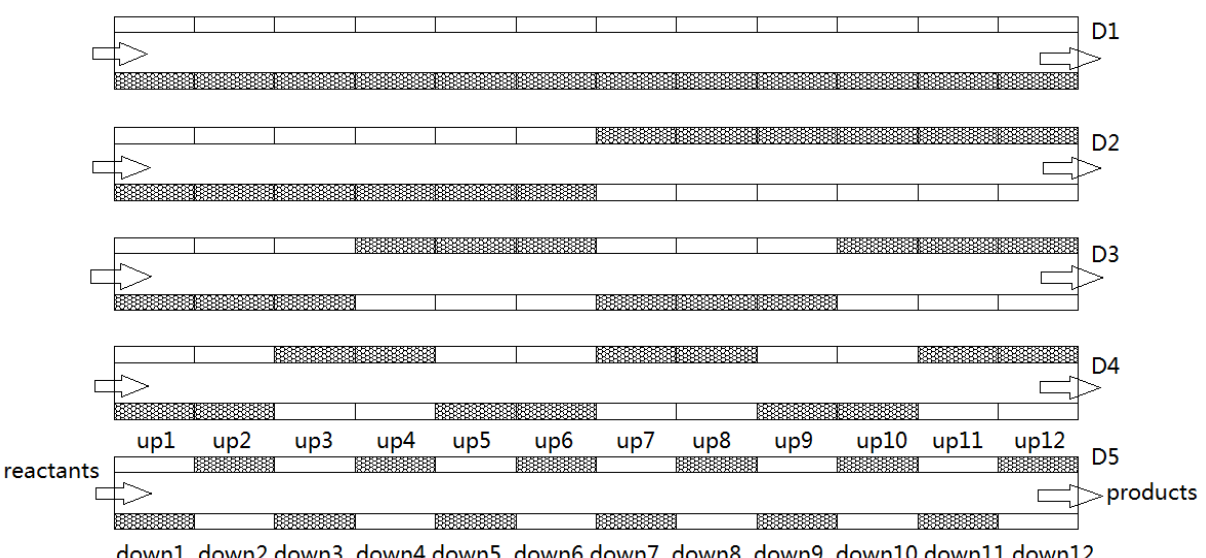

Fig. 10. Design of catalytic surface distribution. 
As for the study of catalytic surface distribution effects on the MSR reactor performance, five surface distributions were defined as shown in Table 1. Where, number of interruption represents the number of discontinuous of catalytic surface with non catalytic surface; take D2 distribution for example, there exists an interruption at down 6 and $u p_{7}$ each, so the interruption number is 2 .

\begin{tabular}{|c|c|c|}
\hline $\begin{array}{c}\text { Types of } \\
\text { distribution }\end{array}$ & Catalytic active surface contained & $\begin{array}{l}\text { Number of } \\
\text { interruption }\end{array}$ \\
\hline D1 & down $_{1} \sim$ down $_{12}$ & 0 \\
\hline D2 & down $_{1} \sim$ down $_{6}$, up $_{7} \sim$ up $_{12}$ & 2 \\
\hline D3 & down $_{1} \sim$ down $_{3}$, up $_{4} \sim$ up $_{6}$, down $_{7} \sim$ down $_{9}$, up $_{10} \sim$ up $_{12}$ & 6 \\
\hline D4 & $\begin{array}{c}\text { down }_{1} \sim \text { down }_{2}, \text { up }_{3} \sim \mathrm{up}_{4}, \text { down }_{5} \sim \text { down }_{6}, \text { up }_{7} \sim \text { up }_{8}, \text { down }_{9} \sim \text { down }_{10}, \\
\text { up }_{11} \sim \text { up }_{12}\end{array}$ & 10 \\
\hline D5 & $\begin{array}{r}\text { down }_{1}, \text { up }_{2}, \text { down }_{3}, \text { up }_{4}, \text { down }_{5}, \text { up }_{6}, \text { down }_{7}, \text { up }_{8}, \text { down }_{9}, \text { up }_{10}, \\
\text { down }_{11}, \text { up }_{12}\end{array}$ & 22 \\
\hline
\end{tabular}

Table 1. Types of catalytic surface distribution with same catalytic activity.

As for the catalytic activity distribution study, three types of distributions were defined as shown in Table2. The total length of the reaction channel $L$ is $12 \mathrm{~mm}$, and height of it is 0.5 $\mathrm{mm}$. In order to achieve the above catalytic surface and activity design, cold spray method for catalytic coating fabrication can be used as was studied in section 3 and an example of interrupted $\mathrm{Cu}$ coating was prepared by this technology. The activity and surface distribution can be modified by altering the spraying parameters such as material of feedstock, temperature and pressure etc.

The assumption of this simulation study is the same as stated in section 2, However, the kinetic model used was simplified to single rate model because the main purpose of this study is to discuss the effect of surface and activity distribution on the reactor performance. So the MSR power function type kinetic model suitable for $\mathrm{Cu} / \mathrm{ZnO} / \mathrm{Al}_{2} \mathrm{O}_{3}$ catalyst was adopted.

$$
r=k_{0} e^{-E a /(R T)} C_{1}^{0.60} C_{2}^{0.45}
$$

Where, $k_{0}$ is the exponential factor, which represents activity of the catalytic surface. As for the catalytic surface distribution study, it equal to $1.2 \times 10^{7} \mathrm{~mol} /\left(\mathrm{m}^{2} \cdot \mathrm{s}\right)$; as for the catalytic

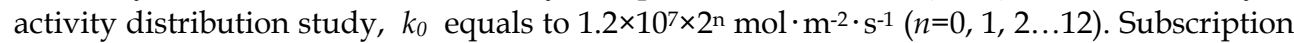
of 1,2 represents $\mathrm{CH}_{3} \mathrm{OH}, \mathrm{H}_{2} \mathrm{O}$ respectively. The activation energy $E a$ is $96.24 \mathrm{~kJ} \cdot \mathrm{mol}^{-1}$. Water and methanol molar ratio was set to 1 in all situations.

\subsection{Results and discussion}

\subsubsection{Effect of catalytic surface distribution}

With increase of temperature, methanol conversion increased at all types of catalytic surface distributions, and this is coincided with experiment results. In order to obtain inlet temperature $T_{\mathrm{in}}$ and velocity $V_{\mathrm{in}}$, catalytic surface distribution effects on methanol conversion, increment of methanol conversion $\Delta X$ was defined based on D1 distribution conversion at same conditions. 


$$
\triangle X=X(\mathrm{D} i)-\mathrm{X}(\mathrm{D} 1),(i=2,3,4,5)
$$

Results showed that $\Delta X$ increased with increasing of $T_{i n}$ and at same temperature

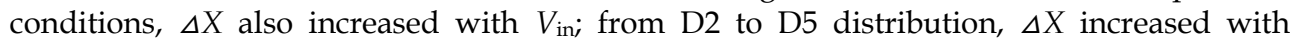
respect to D1. This indicated that catalytic surface distribution contribution on methanol conversion increased with temperature, velocity and interruption of catalytic surfaces as shown in Fig.11.
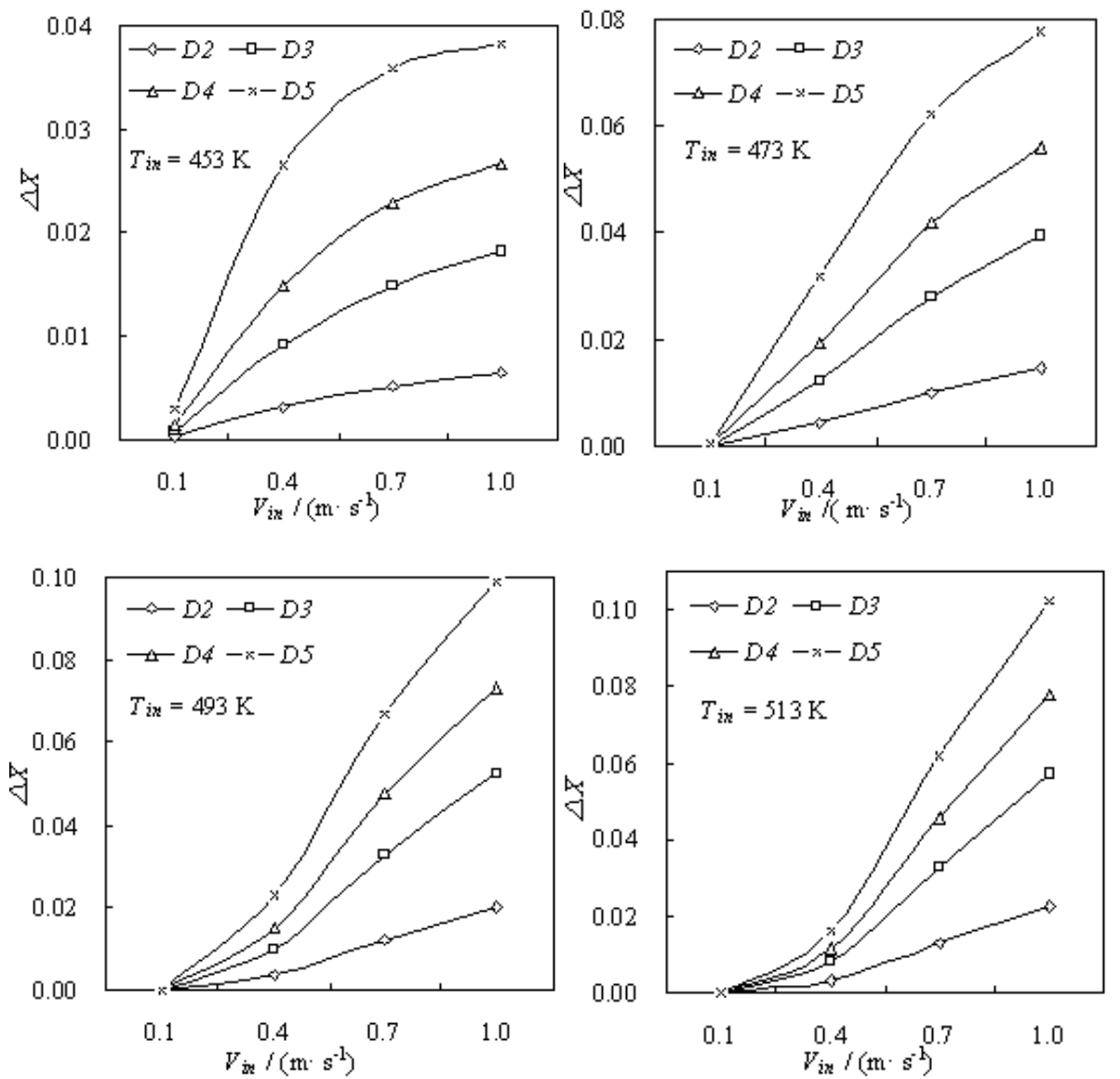

Fig. 11. The effects of $V_{\text {in }}$ and $\mathrm{D} i$ on $\Delta X$ at different temperatures.

At conditions of $T_{\text {in }}=513 \mathrm{~K}, V_{\text {in }}=1.0 \mathrm{~m} / \mathrm{s}$, compared D5 with D1, methanol conversion increased by $10.2 \%$, so in methanol steam reforming system at the same conversion request, this interrupted distribution of catalytic surface can greatly reduce the load of catalyst especially when the noble metal catalyst was adopted. Furthermore, although methanol conversion increased with inlet $T_{\text {in }} V_{\text {in, }}$, the rate of increment was different as can be seen from Fig.11. At inlet temperature of $453 \mathrm{~K}$, rate of $\triangle X$ changed from fast to slow with inlet velocity; at $453 \mathrm{~K}$, rate of $\Delta X$ represented a linearly variation; however, at 
inlet temperature of $493 \mathrm{~K}, 513 \mathrm{~K}$, rate of $\Delta X$ appeared a reverse variation compared to the condition of $453 \mathrm{~K}$. So variation of $\Delta X$ rate existed a turning point with inlet $T_{\text {in }}$ and $V_{\text {in }}$ and this phenomenon should be considered in design of catalytic surface distribution.

From the above analysis it can be seen that through reasonable catalytic surface distribution, methanol conversion can be increased. The reason is that in reaction channel there existed the diffusion limitation of reactants from main stream to catalytic surface; reasonable catalytic surface distribution can increase the local concentration of the reactants at the interruptions. At condition of $513 \mathrm{~K}, 1.0 \mathrm{~m} / \mathrm{s}$, methanol mass fraction of $Y_{1}$ was shown in Fig.12 from D1 to D5 distributions.
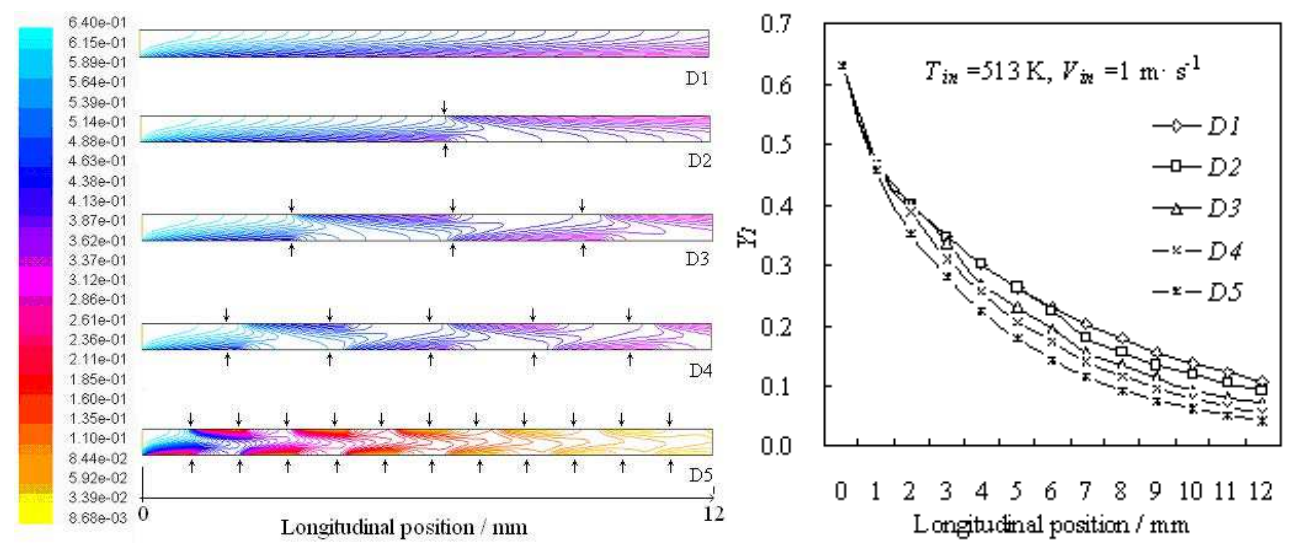

Fig. 12. The change of $Y_{1}$ and average $Y_{1}$ along the reaction channel.

In conventional reaction channel, concentration distribution of reactants was similar to that of D1 situation, however, from D2 to D5 distribution, catalytic surface interruptions broke the continuous concentration distribution, and this resulted in the concentration was higher at local interruptions so on the next catalytic surface after the interruption, concentration of the reactants increased which enhanced the utilization of the catalytic surface.

It is clear that methanol conversion increased from D1 to D5 distribution; actually from D1 to D5 distribution, the number of surface interruption $(n)$ increased, from 0, 2, 6, 10 to 22 respectively. At condition of $T_{\text {in }}=513 \mathrm{~K}, V_{\text {in }}=1.0 \mathrm{~m} / \mathrm{s}$, methanol conversion increment $\Delta X$ was plotting with the surface interruption $n$ as shown in Fig.13. It can be seen that although $\Delta X$ increased with $n$, its rate of increase slowed down, and finally turned into zero. Therefore, it is not that number of surface interruption $(n)$ the bigger the better. In this study surface interruption number $n$ of D5 is enough.

In conclusion, through catalytic surface interrupted distribution methanol conversion increased at the same catalyst loading. So, at the same methanol conversion request, catalyst loading can be reduced. This is not only effective to MSR, but also useful to all the heterogeneous catalysis process on coating catalyst especially for reaction with strong heat effect. 


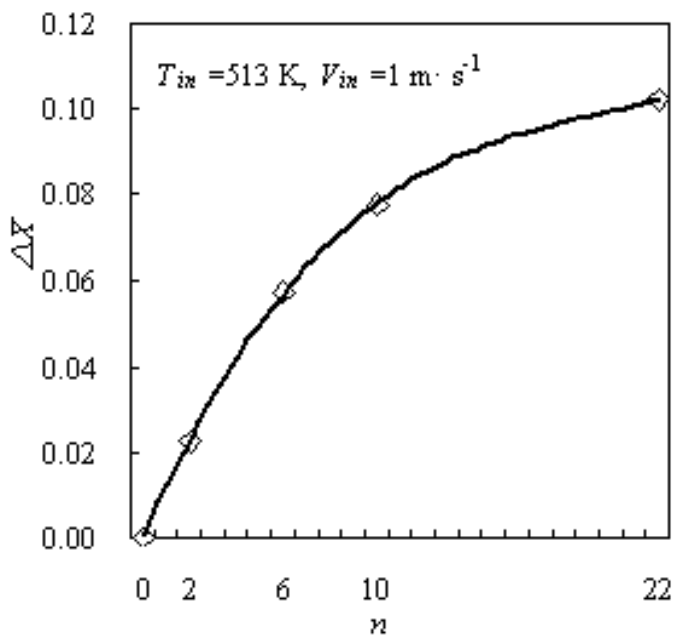

Fig. 13. The change of $\Delta X$ with $n$.

\subsubsection{Effect of catalytic activity distribution}

In this section for catalytic activity distribution study, three types of distributions were defined as shown in Table 2. Effects of catalytic activity on methanol conversion $X$ showed that, at the continuous catalytic surface distribution of $D 1$, methanol conversion increased with catalytic activity (expressed by activity exponential doubling number $n$ ) as shown in Fig.14.

\begin{tabular}{clc}
\hline $\begin{array}{c}\text { Types of } \\
\text { distribution }\end{array}$ & \multicolumn{1}{c}{ Exponential factor $k_{0}\left(\mathrm{~mol} \cdot \mathrm{m}^{-2} \cdot \mathrm{s}^{-1}\right)$} & $\begin{array}{c}\text { Activity exponential } \\
\text { doubling number }\end{array}$ \\
\hline D1 $\quad \begin{array}{l}\text { Activity of down1 } \sim \text { down12 surfaces is } 1.2 \times 10^{7}, \\
2.4 \times 10^{7}, 4.8 \times 10^{7} \ldots \text { respectively; Catalytic surface is } \\
\text { consecutive, Catalytic activity is identical; So there are } \\
12 \text { groups altogether. }\end{array}$ & $0,1,2 \ldots 11$ \\
\hline D2 $\quad \begin{array}{l}\text { Activity of down1 is } 1.2 \times 10^{7} \text {, and down2 is } 2.4 \times 10^{7}, \\
\text { and down3 is } 4.8 \times 10^{7} \ldots, \text { Catalytic surface is } \\
\text { consecutive, Catalytic activity is multiplying; So there } \\
\text { is one group only. }\end{array}$ & $0,1,2 \ldots 11$ \\
\hline D3 & $\begin{array}{l}\text { Activity of down1 is } 1.2 \times 10^{7} \text {, and up2 is } 2.4 \times 10^{7}, \text { and } \\
\text { down3 is } 4.8 \times 10^{7} \ldots, \text { Catalytic surface is interrupted, } \\
\text { Catalytic activity is multiplying; So there is one group } \\
\text { only. }\end{array}$ & $0,1,2 \ldots 11$ \\
\hline
\end{tabular}

Table 2. Types of catalytic activity distribution with different catalytic activity. 

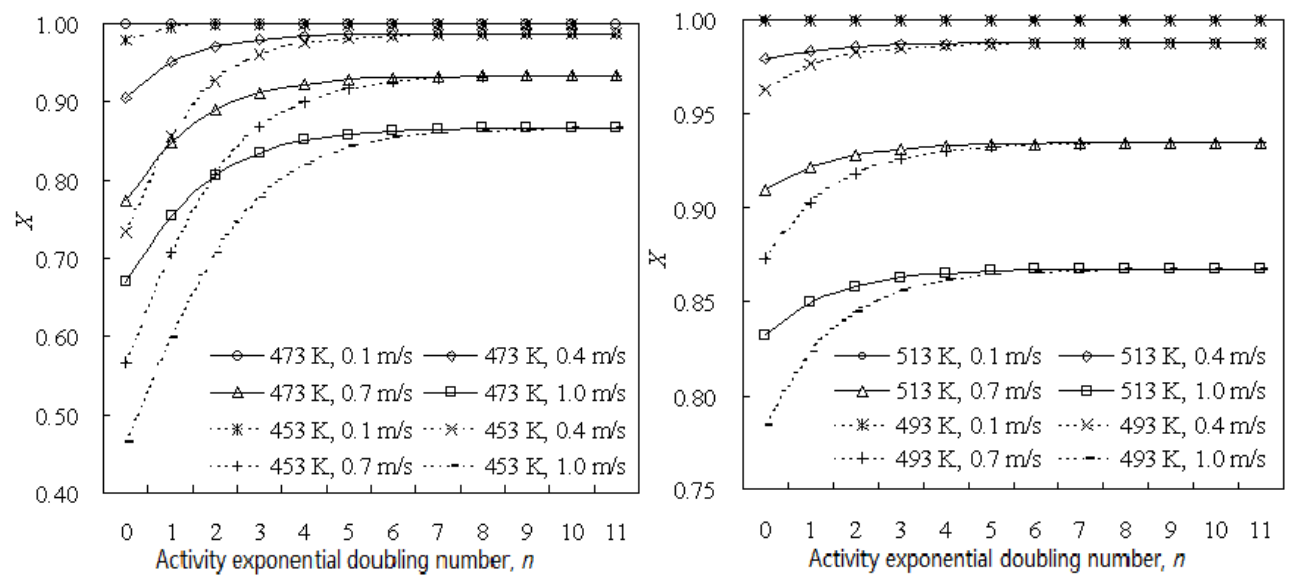

Fig. 14. Effects of $V_{i n}, n$ on $X$ at different $T_{i n}$.

At lower inlet velocity such as $V_{i n}=0.1 \mathrm{~m} \mathrm{~s}^{-1}$, increment of methanol conversion $X$ with $n$ was small, and nearly approached $100 \%$ at all temperatures excepted condition of $T_{\text {in }}=453 \mathrm{~K}$ and $n=0$. This indicated that at lower inlet velocity, MSR was suffered from diffusion limitation, so increasing of catalytic surface activity was non-effective to increment of methanol conversion. However, with the increasing of $V_{i n}$, effect of catalytic surface activity on methanol conversion augmented, indicating a kinetics control effect on methanol conversion. At condition of $T_{i n}=453 \mathrm{~K}, V_{i n}=1.0 \mathrm{~m} \mathrm{~s}^{-1}$, increment of methanol conversion reached $40 \%$ with $n$. On the other hand, with the increase of inlet temperature, effects of catalytic surface activity increment became unconspicuous; at condition of $T_{\text {in }}=513 \mathrm{~K}$, $V_{\text {in }}=1.0 \mathrm{~m} \mathrm{~s}^{-1}$, methanol conversion increased only $3.5 \%$ for $n=11$ compared with $n=0$. Therefore, with the inlet temperature became higher and inlet velocity became slower, effect of activity increment on methanol conversion became smaller. For example, at condition of $T_{\text {in }}=513 \mathrm{~K}, V_{\text {in }}=1.0 \mathrm{~m} \mathrm{~s}^{-1}$, methanol conversion became stable when $n$ reached 6 ; but at condition of $T_{\text {in }}=453 \mathrm{~K}, V_{\text {in }}=1.0 \mathrm{~m} \mathrm{~s}^{-1}$, methanol conversion became stable when $n$ reached 9 . This indicated that with the increment of temperature, process of MSR changed from kinetics control to diffusion limitation, and this should be considered when preparing the catalytic coating.

For other types of catalytic activity distribution on discontinuous surfaces with different activity $(D 2, D 3)$, results of comparing with $D 1(n=0$ and $n=11$ were selected) were shown in Fig.15. It can be seen that at all conditions, sequence of methanol conversion is $D 3>(D 1$, $n=11)>D 2>(D 1, n=0)$. When considering the catalytic surface activity cost of (D1, $n=0)<D 2=D 3<(D 1, n=11)$, it was clear that, methanol conversion of the highest cost of activity was not the biggest. At condition of D3 distribution, its methanol conversion was much greater than the others even if at high inlet velocities. And that activity cost of $D 2$ was much lower than $D 1, n=11$ situation, but its methanol conversion was closed. Therefore, through reasonable catalytic activity distribution, methanol conversion can be improved or at the same conversion request, catalyst activity cost can be reduced. In this study, the distribution of $D 3$ is the best, then comes $D 2$. 

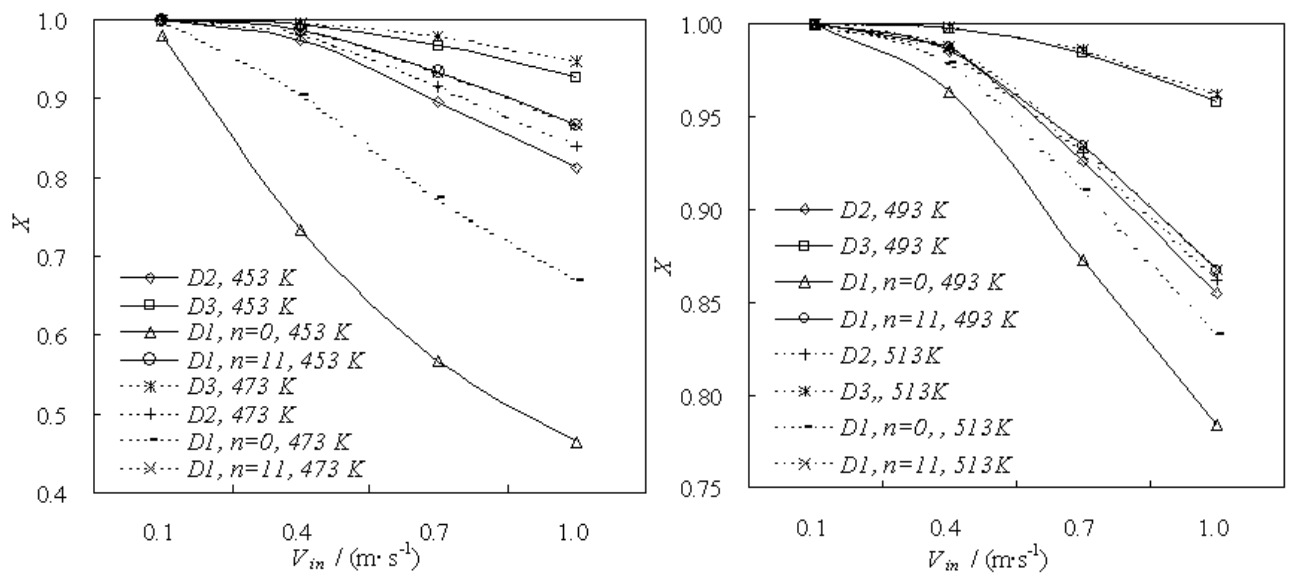

Fig. 15. The effect of $V_{i n}, D$ on $X$ at different $T_{i n}$.

It can also be seen from Fig. 15 that, with the increase of $V_{i n}, X$ decreased, however, the trends were different. For the distribution of $D 1, n=0$, the rate of decrement of $X$ with increase of $V_{\text {in }}$ was changing from big to small for $453 \mathrm{~K}$; and almost linear for $473 \mathrm{~K}$, then small to big for 493 $\mathrm{K}$ and $513 \mathrm{~K}$. However, for the other distribution as shown in Fig.15, trend of methanol conversion decrement with increase of $V_{\text {in }}$ was similar, it was changing from small to big. This indicated that in the kinetics control, diffusion and heat transfer limitation mechanisms of MSR process, it included at least two. At condition of $T_{\text {in }}=453 \mathrm{~K}, V_{\text {in }}=1.0 \mathrm{~m} \cdot \mathrm{s}^{-1}$, methanol conversion for distribution of $D 3$ is greater than $D 1, n=0$ for about $46 \%$ 。

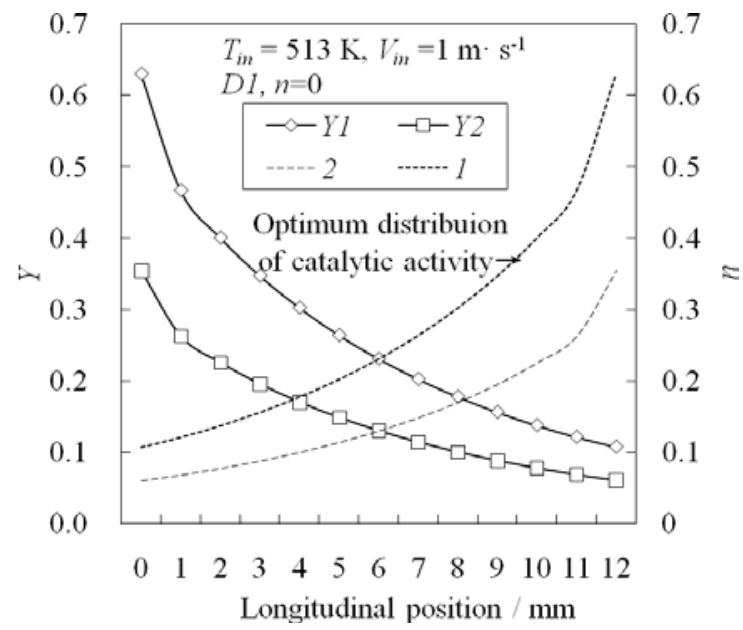

Fig. 16. Mass fraction of methanol $\left(Y_{1}\right)$ and water $\left(Y_{2}\right)$ and optimal catalytic activity distribution $T_{\text {in }}=513 \mathrm{~K}, V_{\text {in }}=1.0 \mathrm{~m} \cdot \mathrm{s}^{-1}$ along the reaction channel.

From the analysis above we can draw a conclusion that, although methanol conversion can be increased by increasing of catalyst activity, but cost of catalyst will be also increase. What 
is more, as MSR process is a strongly endothermic reaction, if high active catalyst is adopted, there will form a cold spot at inlet of the reactor. And this is obvious at condition of reactor with bigger diameter and worse heat transfer, which finally will be harmful to the catalyst and reactor. Therefore, by reasonable catalyst surface and activity distribution, not only methanol conversion can be increased, but difference of cold spot temperature can also be reduced. Consequently, the optimum catalyst activity distribution should be small at reactor inlet, and gradually increase along the reactor, this is especially important for the heterogeneous catalytic reaction with strong heat effect. For instance, at condition of $T_{i n}=513$ $\mathrm{K}, V_{\text {in }}=1.0 \mathrm{~m} \cdot \mathrm{s}^{-1}$, as for the continuous catalyst surface distribution of $D 1, n=0$, mass fraction of methanol $\left(Y_{1}\right)$ and water $\left(Y_{2}\right)$ were gradually decreased along the reaction channel, so the optimum distribution of catalytic activity should be inverse with methanol $\left(Y_{1}\right)$ and water $\left(Y_{2}\right)$ as shown in Fig.16.

\section{Process intensification by reaction and system integration}

\subsection{Simulation method description}

In this section, process of intensification of methanol steam reforming for hydrogen production by system and reaction integration was designed and analyzed.

As for the system integration analysis, a sub-unit in the designed system as shown in Fig.17 was taken out for simulation. The reactor model included one reaction channel, one intermediate platen to separate heating and reaction channel, one heating channel which adopted hot air to simulate the heat from catalytic combustion; height of both channels is 0.5 $\mathrm{mm}$, catalytic area is $72 \mathrm{~mm} \times 42 \mathrm{~mm}$, inlet and outlet diameters of the reactants and products are $10 \mathrm{~mm}$. Steady-state of the model was considered; heating medium of hot air and the reactants were counter flow for heat exchange; outside surface of the unit is adiabatic; gravity of the gases and the radiation heat transfer was also neglected. Kinetic model adopted was the DE and SR parallel mechanism as used in section 2.2.

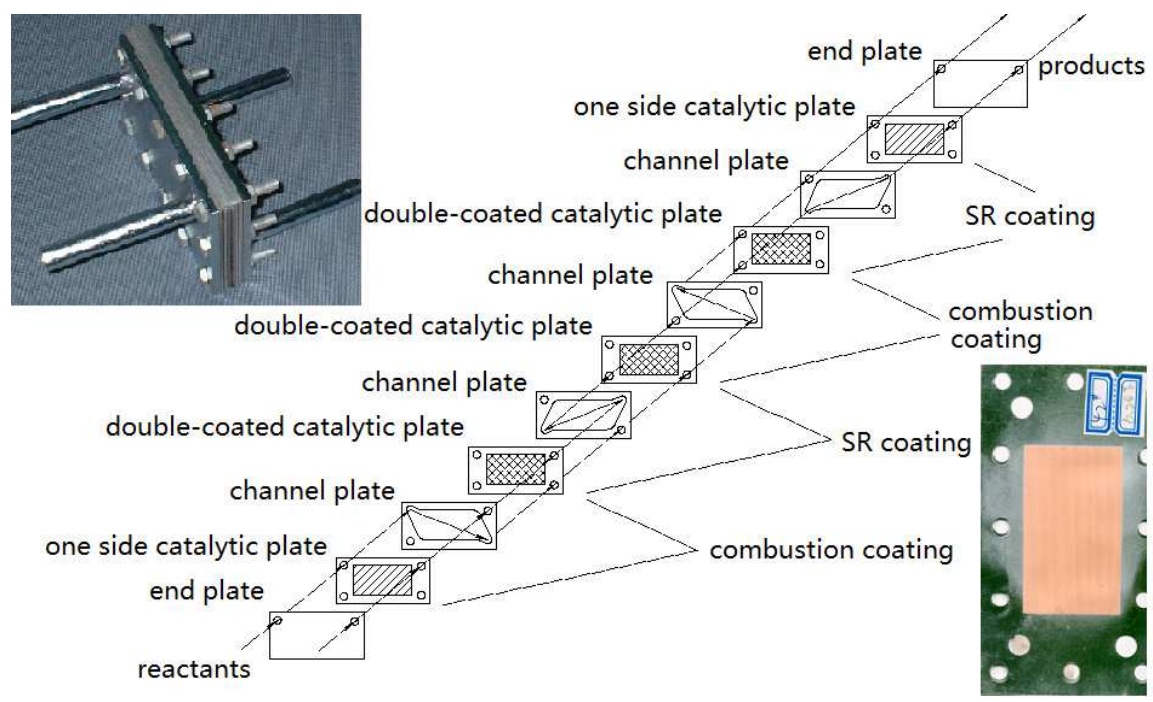

Fig. 17. Methanol steam reformer integration design and the catalytic layer plate. 
As for the reaction analysis integration in methanol steam reforming system, methanol steam reforming (MSR) process, water gas shift (WGS) process and CO selective oxidation (PrOX) process were integrated in one reaction channel with respective catalyst coating as shown in Fig.18. The reactants of methanol, water and oxygen can be supplied together from the reactor inlet as was adopted in this study; or water and oxygen can be separately supplied to WGS and PrOX section in the reactor. The postulated condition was the same as the above reactor integration model; length of the total micro-channel is $12 \mathrm{~mm}$ and height is $0.5 \mathrm{~mm}$; length of the three sections of the reactions was $4 \mathrm{~mm}$ respectively; both up and down of the inner surface in the channel were coated with corresponding catalyst, and the assumption of catalyst coating active to its own reaction only was made.

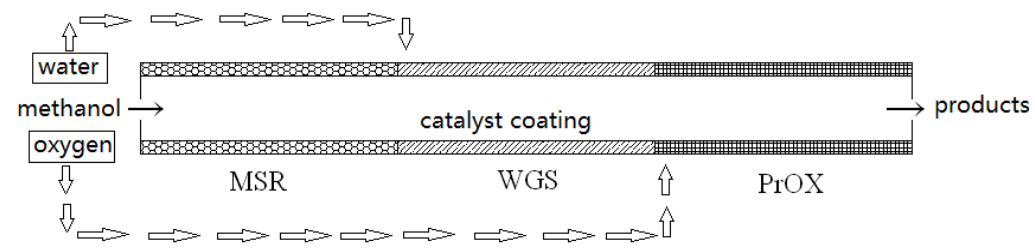

Fig. 18. Reaction integration model in one channel for MSR.

Kinetics of MSR reaction was parallel double rate mechanism model which includs steam reforming (SR) and reverse water gas shift (RWGS) [12]; at the water gas shift section, single rate model of water gas shift reaction was adopted with considering of its reverse reaction [13]; as for the CO selective oxidation model, the single rate model was also used [14]. The reaction equation and its kinetics were listed below.

For the MSR reaction section:

$$
\begin{gathered}
\mathrm{CH}_{3} \mathrm{OH}+\mathrm{H}_{2} \mathrm{O}=\mathrm{CO}_{2}+3 \mathrm{H}_{2} \\
\mathrm{CO}_{2}+\mathrm{H}_{2}=\mathrm{CO}+\mathrm{H}_{2} \mathrm{O} \\
r_{S R}=k_{S R} \exp \left(-\frac{E a_{S R}}{R T}\right) T C_{\mathrm{CH}_{3} \mathrm{OH}}^{0.60} C_{\mathrm{H}_{2} \mathrm{O}}^{0.4} \\
r_{R W G S}=k_{R W G S} \exp \left(-\frac{E a_{R W G S}}{R T}\right) T^{2} C_{\mathrm{CO}_{2}} C_{H_{2}}
\end{gathered}
$$

For the WGS reaction section:

$$
\begin{gathered}
\mathrm{CO}+\mathrm{H}_{2} \mathrm{O} \Leftrightarrow \mathrm{CO}_{2}+\mathrm{H}_{2} \\
r_{W G S}=k_{W G S} \exp \left(-\frac{E a_{W G S}}{R T}\right) T^{2} C_{C O} C_{\mathrm{H}_{2} \mathrm{O}}(1-\beta) \\
\text { 其中, } \beta=\frac{P_{\mathrm{CO}_{2}} P_{\mathrm{H}_{2}}}{K_{e q} P_{\mathrm{CO}} P_{\mathrm{H}_{2} \mathrm{O}}}, K_{e q}=\exp \left(\frac{4577.8}{T}-4.33\right)
\end{gathered}
$$

For the PrOX reaction section: 


$$
\begin{gathered}
\mathrm{CO}+0.5 \mathrm{O}_{2}=\mathrm{CO}_{2} \\
r_{\mathrm{PrOX}}=k_{\mathrm{PrOX}} \exp \left(-\frac{E a_{\mathrm{Pr} O X}}{R T}\right) T^{1.02} C_{\mathrm{CO}}^{0.68} C_{\mathrm{O}_{2}}^{0.34}
\end{gathered}
$$

All the parameters of the kinetics including the exponential factor $k$ and activation energy $E_{a}$ of each reaction were shown in Table3. The outer surface temperature was set to the reaction temperature for each reaction section; but this simplification will be difficult in actual process. The inlet temperature $\mathrm{T}_{\text {in }}$ was set to the temperature of MSR reaction. Four groups of temperatures were calculated, namely MSR-WGS-PrOX of 453K-393K-333K, 473K-413K$353 \mathrm{~K}, 493 \mathrm{~K}-433 \mathrm{~K}-373 \mathrm{~K}$, 513K-453K-393; also four groups of reactants inlet ratios $\mathrm{m}_{\mathrm{H} 2 \mathrm{O}}: \mathrm{m}_{\mathrm{CH} 3 \mathrm{OH}}: \mathrm{m}_{\mathrm{O} 2}$ were considered as the following: 0.399:0.6:0.0001, 0.449:0.55:0.001, 0.49:0.5:0.01 and 0.5:0.45:0.05; as for the inlet velocity $V_{\text {in }}$ effects study, $0.4 \mathrm{~m} \cdot \mathrm{s}^{-1}, 0.7 \mathrm{~m} \cdot \mathrm{s}^{-1}$, $1.0 \mathrm{~m} \cdot \mathrm{s}^{-1}, 1.3 \mathrm{~m} \cdot \mathrm{s}^{-1}$ were considered.

\begin{tabular}{|c|c|c|c|}
\hline section & reaction & $\mathrm{k} / \mathrm{mol} \mathrm{m}^{-2} \mathrm{~s}^{-1}$ & $E a / \mathrm{J} \mathrm{kmol}^{-1}$ \\
\hline \multirow{4}{*}{ MSR } & SR & $2.46 \times 10^{6}$ & $7.6 \times 10^{7}$ \\
\cline { 2 - 4 } & RWGS & $2.52 \times 10^{5}(453 \mathrm{~K})$ & $1.08 \times 10^{8}$ \\
\cline { 2 - 4 } & RWGS & $3.86 \times 10^{5}(473 \mathrm{~K})$ & $1.08 \times 10^{8}$ \\
\cline { 2 - 4 } & RWGS & $5.72 \times 10^{5}(493 \mathrm{~K})$ & $1.08 \times 10^{8}$ \\
\cline { 2 - 4 } & RWGS & $8.21 \times 10^{5}(513 \mathrm{~K})$ & $1.08 \times 10^{8}$ \\
\hline \multirow{4}{*}{ WGS } & WGS & $8.12 \times 10^{7}$ & $4.74 \times 10^{7}$ \\
\cline { 2 - 4 } & RWGS & $5.39 \times 10^{4}(333 \mathrm{~K})$ & $4.74 \times 10^{7}$ \\
\cline { 2 - 4 } & RWGS & $9.19 \times 10^{4}(353 \mathrm{~K})$ & $4.74 \times 10^{7}$ \\
\cline { 2 - 4 } & RWGS & $1.58 \times 10^{5}(373 \mathrm{~K})$ & $4.74 \times 10^{7}$ \\
\cline { 2 - 4 } & RWGS & $2.52 \times 10^{5}(393 \mathrm{~K})$ & $4.74 \times 10^{7}$ \\
\hline PrOX & PrOX & $4.89 \times 10^{3}$ & $2.7 \times 10^{7}$ \\
\hline
\end{tabular}

Table 3. Parameters of kinetic models.

\subsection{Results and discussion}

\subsubsection{Microreactor integration simulation results}

In calculation, inlet hot air temperature is $750 \mathrm{~K}$ and inlet velocity is $3 \mathrm{~m} / \mathrm{s}$. Effect of different inlet parameters on outlet product molar fraction $F_{m}$, methanol conversion $X(\mathrm{MeOH})$ and outlet temperature $T_{\text {out }}$ was considered. The range of temperature $T_{\text {in }}$ of reactants was $493 \mathrm{~K}$ to $613 \mathrm{~K}$; range of inlet velocity $V_{\text {in }}$ was $0.144 \mathrm{~m} / \mathrm{s}$ to $2.88 \mathrm{~m} / \mathrm{s}$; inlet water methanol molar ratio was 1 to 1.6. The similar variation trend of increasing of methanol conversion and hydrogen yield with inlet temperature was got because MSR process is a strongly endothermic reaction; with the increase of inlet velocity, the contact time of reactants with catalyst reduced, part of the reactants flowed out the reactor without reaction which resulted in the lower conversion of methanol and respectively higher content of methanol and water; similarly, with the increase of water and methanol molar ratio, methanol conversion increased, however, hydrogen content in the products decreased as shown in Fig.19 with constant inlet velocity of $2.88 \mathrm{~m} / \mathrm{s}$. 
Analysis of outlet temperature showed that, it rarely changed with inlet temperature, indicating that with the rise of inlet temperature, the absorption of heat by the reaction also increased. With the increase of inlet velocity, although methanol conversion decreased, the total mass of reactant reacted increased, therefore, at same heating condition, there formed a temperature decrease of $4 \mathrm{~K}$. When water and methanol molar ratio increased, there was a fluctuation of the outlet temperature, this stated that water in the MSR system exist an optimum value for the heat balance, it was about 1.3. To sum up, fluctuation of outlet temperature with inlet parameter of reactants was small, so it was enough for the heat needed supplied by hot air.

At condition of $V_{i n}=2.88 \mathrm{~m} / \mathrm{s}, T_{i n}=493 \mathrm{~K}, S / M=1.3$, temperature distribution in the channel was studied and a temperature drop was found at inlet of both hot air channel and reactant reaction channel. This is consistent with the above study in section 1 for cold spot discussion.
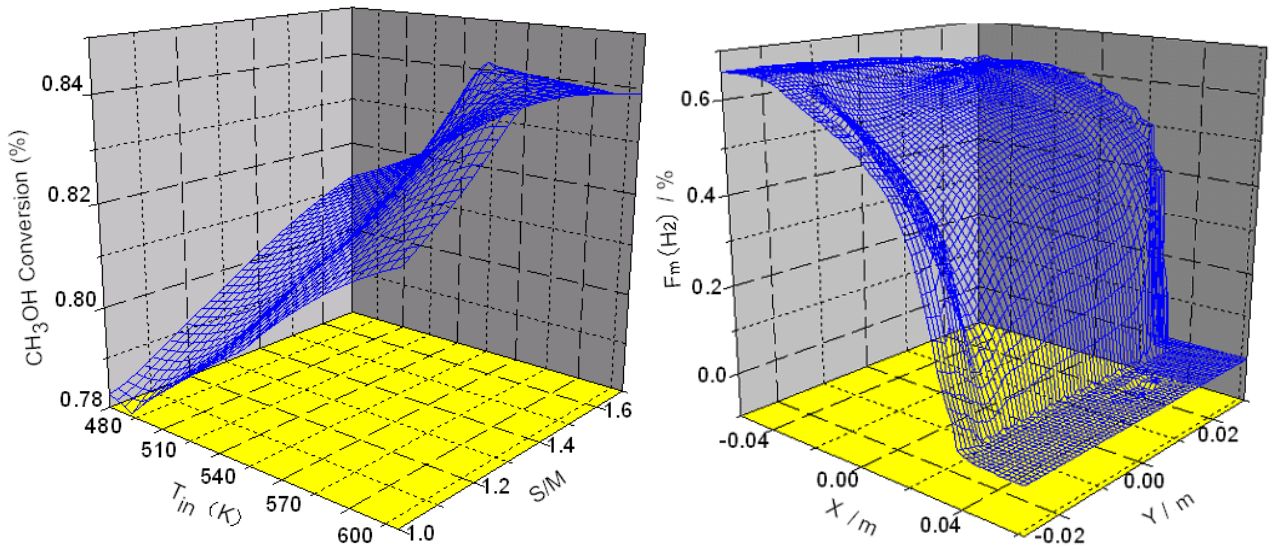

Fig. 19. Methanol conversion with $S / M, T_{\text {in }}\left(V_{\text {in }}=2.88 \mathrm{~m} / \mathrm{s}\right)$ and $F_{m}\left(H_{2}\right)$ distribution in reaction channel $\left(V_{\text {in }}=2.88 \mathrm{~m} / \mathrm{s}, T_{\text {in }}=493 \mathrm{~K}, S / M=1.3\right)$.

Based on the previous accounts, temperature in the reaction channel can be optimized by properly coupling of inlet hot air temperature and reactant inlet temperature. Another way to improve reactor performance is the altering of reactor sizes and catalytic surface and activity distribution. At condition of $V_{\text {in }}=2.88 \mathrm{~m} / \mathrm{s}, T_{\text {in }}=493 \mathrm{~K}, S / M=1.3$, methanol conversion in the reactor was shown in Fig.19. The reactor outlet methanol conversion reached $79.8 \%$, so it can be seen that microreactor can maintain higher hydrogen molar fraction and methanol conversion at high reactant flow rate.

\subsubsection{Reaction integration simulation results}

In this section, effects of inlet parameters such as inlet temperature $T_{i n}$, inlet velocity $V_{\text {in }}$ and inlet water, methanol, oxygen mass fraction ratio $m_{\mathrm{H} 2 \mathrm{O}}: m_{\mathrm{CH} 3 \mathrm{OH}}: m_{\mathrm{O} 2}$ on methanol conversion $X_{\mathrm{CH} 3 \mathrm{OH}}$, oxygen conversion $\mathrm{X}_{\mathrm{O} 2}$, outlet hydrogen and $\mathrm{CO}$ molar fraction $F_{\mathrm{H} 2}$ and $F_{\mathrm{CO}}$ were investigated. Results showed that, $\mathrm{X}_{\mathrm{CH} 3 \mathrm{OH}}$ decreased with inlet velocity, and increased with methanol, oxygen mass fraction ratio; at condition of $T_{i n}=493 \mathrm{~K}, V_{i n}=0.4 \mathrm{~m} \mathrm{~s}^{-1}$, it reached its maximum value of 0.995; however, increasing of oxygen inlet mass fraction was disadvantageous to outlet hydrogen content; at condition of $T_{\text {in }}=453 \mathrm{~K}, V_{\text {in }}=0.4 \mathrm{~m} \mathrm{~s}^{-1}$ and $m_{\mathrm{H} 2 \mathrm{O}}: m_{\mathrm{CH} 3 \mathrm{OH}}: m_{\mathrm{O} 2}=0.3999: 0.60: 0.0001, F_{\mathrm{H} 2}$ reached its maximum value. 
The conversion of oxygen $X_{\mathrm{O} 2}$ was not the same with methanol; at water, methanol, oxygen molar ratio of 0.3999:0.60:0.0001 and inlet temperature of $453 \mathrm{~K}, \mathrm{X}_{\mathrm{O} 2}$ changed from increase to decrease with inlet velocity and reached it maximum of 0.977 at $V_{\text {in }}=0.4 \mathrm{~m} \mathrm{~s}^{-1}$; however, at inlet temperature of $493 \mathrm{~K}$ and $513 \mathrm{~K}, \mathrm{X}_{\mathrm{O} 2}$ decreased with inlet velocity; when oxygen increased in the reactant to $\mathrm{m}_{\mathrm{H} 2 \mathrm{O}}: \mathrm{m}_{\mathrm{CH} 3 \mathrm{OH}}: \mathrm{m}_{\mathrm{O} 2}$ of $0.449: 0.55: 0.001$, at inlet temperature of $453 \mathrm{~K}$ and $473 \mathrm{~K}, \mathrm{X}_{\mathrm{O} 2}$ increased with inlet velocity; but, at temperature of $493 \mathrm{~K}$ and $513 \mathrm{~K}$, it increased firstly and then decreased with $V_{\text {in }}$. At the other $m_{\mathrm{H} 2 \mathrm{O}}: m_{\mathrm{CH} 3 \mathrm{OH}}: m_{\mathrm{O} 2}$ condition of 0.49:0.50:0.01 and 0.50:0.45:0.05, $X_{\mathrm{O} 2}$ increased with inlet velocity; therefore inlet oxygen content in this reaction model is very sensitive and should be carefully adjusted.

As for the $\mathrm{CO}$ outlet molar fraction $\mathrm{F}_{\mathrm{CO}}$, it increased with inlet velocity at same temperature and inlet component and this is not the same compared with MSR process. At condition of $\mathrm{T}_{\text {in }}=453 \mathrm{~K}, V_{\text {in }}=0.4 \mathrm{~m} \mathrm{~s}^{-1}$ and $\mathrm{m}_{\mathrm{H} 2 \mathrm{O}}: \mathrm{m}_{\mathrm{CH} 3 \mathrm{OH}}: \mathrm{m}_{\mathrm{O} 2}=0.50: 0.45: 0.05$, minimum CO molar fraction of $4.03 \times 10^{-9}$ was got. Because CO concentration limitation for PEMFC is below 50 ppm, outlet of hydrogen molar fraction for the reformer should be increased to its greatest extent in this $\mathrm{CO}$ requirement. In this study, the optimum condition was that $T_{\text {in }}=453 \mathrm{~K}, V_{\text {in }}=0.4$ $\mathrm{m} \cdot \mathrm{s}^{-1}$ and $m_{\mathrm{H} 2 \mathrm{O}}: m_{\mathrm{CH} 3 \mathrm{OH}}: m_{\mathrm{O}_{2}}=0.3699: 0.63: 0.0001$, at which methanol conversion reached $98.8 \%$, oxygen conversion reached $15.2 \%$, and outlet hydrogen molar fraction and CO molar fraction were $74 \%$ and $3.43 \times 10^{-8}$ respectively.

At optimum condition of $T_{i n}, V_{i n}$ and $m_{\mathrm{H} 2 \mathrm{O}}: m_{\mathrm{CH}} \mathrm{OH}: m_{\mathrm{O} 2}$, the component mass fraction along the flow direction in the reactor channel was studied as shown in Fig.20.
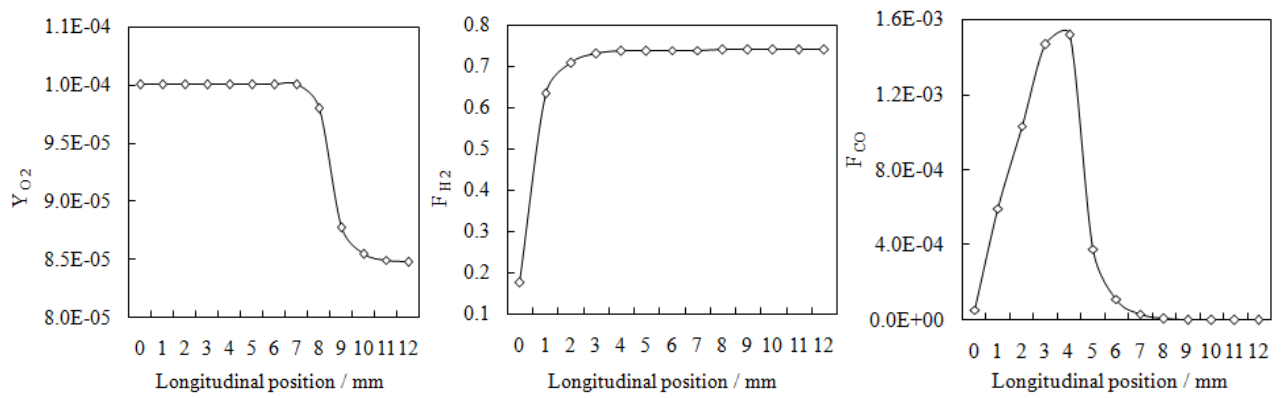

Fig. 20. Mass fraction distribution along the reaction channel.

As can be seen from Fig.20, marginala oxygen from inlet of the reactor was mainly consumed at the PrOX section, which received a conversion of only $15.2 \%$; however, it was just due to the marginala oxygen that CO reduced to $3.43 \times 10^{-8}$ from the MSR section outlet of $0.152 \%$. Through the WGS reaction section, CO reduced to $1.0 \times 10^{-5}$, which was still greater than the requirement of PEMFC. But the hydrogen content in the reactor after MSR reaction section did not increased notably; After WGS reaction section, it only increased by $0.314 \%$ and even slightly reduced after the PrOX section.

\section{Conclusions and challenges}

1. Through the adoption of micro-reactors, cold spot effect of methanol steam reforming for hydrogen production can be decreased compared with conventional reactors. 
Optimum conditions of the reactor were obtained. Hydrogen yield reached $0.2 \mathrm{~mol} /\left(\mathrm{h} \cdot \mathrm{g}_{\text {cat }}\right)$ under condition of $T_{r}=260{ }^{\circ} \mathrm{C}, W / \mathrm{M}=1.3$ and $W G H V=0.2 \mathrm{~h}^{-1}$, which can provide hydrogen for $10.2 \mathrm{~W}$ PEMFC with a hydrogen utilization of $80 \%$ and an fuel cell efficiency of $60 \%$. A 3-D model coupling with parallel reaction kinetics was obtained by data fitting to describe its performance. Furthermore, gradually increased catalyst activity in the reaction channel can be used to further reduce the cold spot effect; Hydrogen content at reactor outlet increased by about $8.5 \%$ compared with catalyst uniform distribution condition; while outlet $\mathrm{CO}$ content reduced to less than $0.13 \%$.

2. Cold spray technology was successfully used to catalytic coatings fabrication for fuel reforming reaction and all the powers were effectively deposited onto the substrates. Components of the coatings were approximately identical to the initial powders. Performance of the coating was influenced by impact velocity and broken character of the particles especially for the $\mathrm{NiO} / \mathrm{Al}_{2} \mathrm{O}_{3}$ and $\mathrm{CuO} / \mathrm{ZnO} / \mathrm{Al}_{2} \mathrm{O}_{3}$ catalytic coatings. For the $\mathrm{Cu}$ coating, carbon deposition is serious which resulted in nonstable activity in methanol steam reforming compared with $\mathrm{Cu}-\mathrm{Al}_{2} \mathrm{O}_{3}$ coating. At condition of inlet temperature $265^{\circ} \mathrm{C}, \mathrm{W} / \mathrm{M}$ of 1.3 , space velocity of $162 \mathrm{~h}^{-1}, \mathrm{H}_{2}$ content in the products for $\mathrm{CuO} / \mathrm{ZnO} / \mathrm{Al}_{2} \mathrm{O}_{3}$ catalytic coating reaches $52.3 \%$, whereas $\mathrm{CO}$ content is only $0.60 \%$. Methane primary steam reforming on cold sprayed $\mathrm{NiO} / \mathrm{Al}_{2} \mathrm{O}_{3}$ coating also indicated a superior character to kernel catalyst in packed bed reactor as its high output.

3. Through interrupted distribution of catalytic surface, at same conditions methanol conversion could be improved although the temperature in reaction channel became uneven. So in micro-reactors which utilize coating catalyst, this interrupted distribution of surface can improve the efficiency of catalyst and thus reduce loading and cost of reforming catalyst. The optimal activity distribution was that the activity should be low at inlet, along with the reactor channel, the activity gradually increased. This kind of activity distribution can also be used to decrease the cold spot temperature difference in the reactor. The 3-D simulation results of MSR for hydrogen production in selfdesigned plate micro reactor showed that micro-reactors can maintain a high hydrogen molar fraction and methanol conversion at high reactant flow rate. It is also reasonable to integrate all reaction units in fuel reforming system in one channel to mach up PEMFC for $\mathrm{CO}$ requirement.

Therefore, through the adoption of both micro-scale reactors and coating catalyst, heat and mass transfer in the reaction channel for hydrogen production by fuel reforming can be enhanced resulting in the improvement of reactor performance. Nowadays, research of process intensification by the above methods becomes more and more, and it is beneficial for the development of hydrogen production through hydrocarbon fuel reforming technology. All the endeavors will promote the application of hydrogen energy. We look forward to the day of hydrogen economy coming soon.

\section{Acknowledgements}

The authors acknowledge the support of National Natural Science Foundation of China (50906104) and project No.CDJZR10140010 supported by Fundamental Research Funds for the Central Universities. 


\section{Nomenclature}

\begin{tabular}{|c|c|c|c|}
\hline$C$ & molar concentration, $\mathrm{kmol} / \mathrm{m}^{3}$ & $P$ & mixed gas pressure, $\mathrm{Pa}$ \\
\hline$C_{p}$ & $\begin{array}{l}\text { Isobaric specific heat capacity, } \\
\mathrm{J} /(\mathrm{mol} \cdot \mathrm{K})\end{array}$ & $\mu$ & $\begin{array}{l}\text { mixed gas viscosity coefficient, } \\
\mathrm{kg} /(\mathrm{m} \cdot \mathrm{s})\end{array}$ \\
\hline$D$ & $\begin{array}{l}\text { effective diffusion coefficient, } \mathrm{m}^{2} / \mathrm{s} \text { or } \\
\text { thickness, } \mathrm{mm} \text {; or catalyst and catalytic } \\
\text { coating distribution types }\end{array}$ & $T, T_{\mathrm{r}}$ & $\begin{array}{l}\text { mixed gas temperature and } \\
\text { reaction temperature, } \mathrm{K} \text { or }{ }^{\circ} \mathrm{C}\end{array}$ \\
\hline$\rho$ & mixed gas density, $\mathrm{kg} / \mathrm{m}^{3}$ & $L$ & $\begin{array}{l}\text { Channel length or channel } \\
\text { subsection length, mm }\end{array}$ \\
\hline$V, v$ & mixed gas velocity, $\mathrm{m} / \mathrm{s}$ & $M$ & molar mass, $\mathrm{kg} / \mathrm{mol}$ \\
\hline$Y, F$ & component molar fraction, $\%$ & $m$ & mass fraction, $\%$ \\
\hline$V$ & $\begin{array}{l}\text { mixed gas velocity, } \mathrm{m} / \mathrm{s} \text { or rate of inlet } \\
\text { liquid flow } \mathrm{ml} / \mathrm{min}\end{array}$ & $S$ & selectivity, \% \\
\hline$q, q$ & heat of reaction, $\mathrm{W} / \mathrm{m}^{2}$ & $\begin{array}{l}\mathrm{S} / \mathrm{M} \\
\mathrm{W} / \mathrm{M}\end{array}$ & water methanol ratio \\
\hline $\begin{array}{c}R, r, \\
a\end{array}$ & reaction rate, mol/ (g $\left.\mathrm{g}_{\text {cat }} \mathrm{h}\right)$ & $E_{\mathrm{a}}$ & activation energy, $\mathrm{kJ} / \mathrm{mol}$ \\
\hline$r^{\prime}$ & reaction rate, $\mathrm{kmol} /\left(\mathrm{m}^{2} \mathrm{~s}\right)$ & $h$ & $\begin{array}{l}\text { height of channel, } \mathrm{mm} \text { or specific } \\
\text { enthalphy, } \mathrm{J} / \mathrm{kg}\end{array}$ \\
\hline$R$ & universal gas constant, $\mathrm{kJ} /(\mathrm{molK})$ & $\mathrm{H}$ & height of channel, mm \\
\hline$H^{0}$ & standard enthalpy of formation, $\mathrm{J} / \mathrm{kg}$ & $X$ & conversion, $\%$ \\
\hline$k$ & reaction rate constant, $\mathrm{mol} /\left(\mathrm{kg}_{\mathrm{cat}} \mathrm{s}\right)$ & WHSV & liquid space velocity, $\mathrm{h}^{-1}$ \\
\hline K & reaction equilibrium constant & $k_{0}, k_{0}^{\prime}$ & frequency factor, $\mathrm{mol} /\left(\mathrm{kg}_{\text {cat }} \mathrm{s}\right)$ \\
\hline $\mathrm{a}, \mathrm{b}$ & thickness, mm & $\begin{array}{l}\text { up, } \\
\text { down }\end{array}$ & mark of up and down channel \\
\hline $\mathrm{n}$ & $\begin{array}{l}\text { number of interruption or activity } \\
\text { exponential doubling number }\end{array}$ & $\mathrm{W} / \mathrm{F}$ & $\begin{array}{l}\text { ratio of mole flow rate and catalyst } \\
\text { weight, } \mathrm{g} \cdot \mathrm{h} / \mathrm{mol}\end{array}$ \\
\hline \multicolumn{4}{|c|}{ Subscript: } \\
\hline 0 , in & inlet parameters & out & outlet parameters \\
\hline 1,2 & $\begin{array}{l}\text { mark of channel or catalyst coating } \\
\text { subsection }\end{array}$ & $s=1 \sim 5$ & $\begin{array}{l}\text { reactants and products of } \mathrm{CH}_{3} \mathrm{OH} \text {, } \\
\mathrm{H}_{2} \mathrm{O}, \mathrm{H}_{2}, \mathrm{CO}, \mathrm{CO}_{2}\end{array}$ \\
\hline $\mathrm{i}$ & $\begin{array}{l}\text { mark of channel or catalyst coating } \\
\text { subsection }\end{array}$ & $\left(\mathrm{CH}_{3} \mathrm{OH}\right)$ & represent of methanol parameter \\
\hline $\mathrm{w}$ & reaction channel wall & $\left(\mathrm{CO}_{2}\right)$ & represent of $\mathrm{CO}_{2}$ parameter \\
\hline cat. & represent of catalyst parameter & $\left(\mathrm{H}_{2}\right)$ & represent of $\mathrm{H}_{2}$ parameter \\
\hline$(\mathrm{F})$ & molar fraction & $\left(\mathrm{H}_{2} \mathrm{O}\right)$ & represent of $\mathrm{H}_{2} \mathrm{O}$ parameter \\
\hline WGS & water gas shift reaction & $(\mathrm{CO})$ & represent of CO parameter \\
\hline SR & steam reforming reaction & $\mathrm{O}_{2}$ & represent of $\mathrm{O}_{2}$ parameter \\
\hline $\mathrm{DE}$ & methanol decomposition & $\triangle$ & variable difference \\
\hline RWGS & reverse water gas shift reaction & $(\mathrm{X})$ & represent of conversion \\
\hline
\end{tabular}




\section{References}

[1] Carl-Jochen Winter. (2009). Hydrogen energy - Abundant, efficient, clean: A debate over the energy-system-of-change. International Journal of Hydrogen Energy, Vol. 34, No. 14, Supplement 1, (July 2009), pp. (S1-S52), 0360-3199

[2] Anand S. Joshi, Ibrahim Dincer, Bale V. Reddy. (2010). Exergetic assessment of solar hydrogen production methods. International Journal of Hydrogen Energy, Vol. 35, No. 10, (May 2010), pp. (4901-4908), 0360-3199

[3] Jianlong Wang, Wei Wan. (2009). Experimental design methods for fermentative hydrogen production: A review. International Journal of Hydrogen Energy, Vol. 34, No. 1, (January 2009), pp. (235-244), 0360-3199

[4] Michael G. Beaver, Hugo S. Caram, Shivaji Sircar. (2010). Sorption enhanced reaction process for direct production of fuel-cell grade hydrogen by low temperature catalytic steam-methane reforming. Journal of Power Sources, Vol. 195, No. 7, 2, (April 2010), pp. (1998-2002), 0378-7753

[5] Guangming Zeng, Ye Tian, Yongdan Li. (2010). Thermodynamic analysis of hydrogen production for fuel cell via oxidative steam reforming of propane. International Journal of Hydrogen Energy, Vol. 35, No. 13, (July 2010), pp. (6726-6737), 0360-3199

[6] Stefan Martin, Antje Wörner. (2011). On-board reforming of biodiesel and bioethanol for high temperature PEM fuel cells: Comparison of autothermal reforming and steam reforming. Journal of Power Sources, Vol. 196, No. 6, 15, (March 2011), pp. (31633171), 0378-7753

[7] Feng Wang, Dingwen Zhang, Shiwei Zheng, Bo Qi. (2010). Characteristic of cold sprayed catalytic coating for hydrogen production through fuel reforming. International Journal of Hydrogen Energy, Vol. 35, No. 15, (August 2010), pp. (8206-8215), 03603199

[8] M. H. Akbari, A. H. Sharafian Ardakani, M. Andisheh Tadbir. (2011). A microreactor modeling, analysis and optimization for methane autothermal reforming in fuel cell applications. Chemical Engineering Journal, Vol. 166, No. 3, 1 (February 2011), pp. (1116-1125), 1385-8947

[9] Akira Nishimura, Nobuyuki Komatsu, Go Mitsui, Masafumi Hirota, Eric Hu. (2009). $\mathrm{CO}_{2}$ reforming into fuel using $\mathrm{TiO}_{2}$ photocatalyst and gas separation membrane. Catalysis Today, Vol. 148, No. 3-4, 30 (November 2009), pp. (341-349), 0920-5861

[10] Feng Wang, Longjian Li, Bo Qi, Wenzhi Cui, Mingdao Xin, Qinghua Chen, Lianfeng Deng. (2008). Methanol steam reforming for hydrogen production in a minireactor. Journal of Xi 'An J iao Tong University, Vol. 42, No. 4, (April 2008), pp. (341-349), 509514, 0253-987X

[11] Feng Wang, Jing Zhou, Zilong An, Xinjing Zhou. (2011). Characteristic of Cu-based catalytic coating for methanol steam reforming prepared by cold spray. Advanced Materials Research, Vol. 156-157, (2011), pp. (68-73), 1022-6680

[12] H. Purnama, T. Ressler, R. E. Jentoft, H. Soerijanto, R. Schlögl, R. Schomäcker. (2004). $\mathrm{CO}$ Formation / Selectivity for Steam Reforming of Methanol with a Commercial $\mathrm{CuO} / \mathrm{ZnO} / \mathrm{Al}_{2} \mathrm{O}_{3}$ Catalyst. Applied Catalysis A: General, Vol. 259, No.1, 8, (March 2004), pp. (83-94), 0926-860X

[13] Yongtaek Choi, Harvey G Stenger. (2003). Water Gas Shift Reaction Kinetics and Reactor Modeling for Fuel Cell Grade Hydrogen. Journal of Power Sources, Vol. 124, No. 2, (November 2003), pp. (432-439), 0378-7753 
[14] Y. H. Wang, J. L. Zhu, J. C. Zhang, L.F. Song, J. Y. Hu, S. L. Ong, W. J. Ng. (2006). Selective Oxidation of $\mathrm{CO}$ in Hydrogen-rich Mixtures and Kinetics Investigation on Platinum-gold Supported on Zinc Oxide Catalyst. Journal of Power Sources, Vol. 155, No. 2, (April 2006), pp. (440-446), 0378-7753 


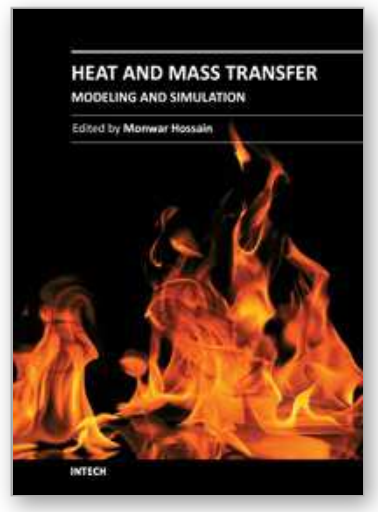

\author{
Heat and Mass Transfer - Modeling and Simulation \\ Edited by Prof. Md Monwar Hossain
}

ISBN 978-953-307-604-1

Hard cover, 216 pages

Publisher InTech

Published online 22, September, 2011

Published in print edition September, 2011

This book covers a number of topics in heat and mass transfer processes for a variety of industrial applications. The research papers provide advances in knowledge and design guidelines in terms of theory, mathematical modeling and experimental findings in multiple research areas relevant to many industrial processes and related equipment design. The design of equipment includes air heaters, cooling towers, chemical system vaporization, high temperature polymerization and hydrogen production by steam reforming. Nine chapters of the book will serve as an important reference for scientists and academics working in the research areas mentioned above, especially in the aspects of heat and mass transfer, analytical/numerical solutions and optimization of the processes.

\title{
How to reference
}

In order to correctly reference this scholarly work, feel free to copy and paste the following:

Feng Wang, Guoqiang Wang and Jing Zhou (2011). Process Intensification of Steam Reforming for Hydrogen Production, Heat and Mass Transfer - Modeling and Simulation, Prof. Md Monwar Hossain (Ed.), ISBN: 978953-307-604-1, InTech, Available from: http://www.intechopen.com/books/heat-and-mass-transfer-modelingand-simulation/process-intensification-of-steam-reforming-for-hydrogen-production

\section{INTECH}

open science | open minds

\section{InTech Europe}

University Campus STeP Ri

Slavka Krautzeka 83/A

51000 Rijeka, Croatia

Phone: +385 (51) 770447

Fax: +385 (51) 686166

www.intechopen.com

\section{InTech China}

Unit 405, Office Block, Hotel Equatorial Shanghai

No.65, Yan An Road (West), Shanghai, 200040, China

中国上海市延安西路65号上海国际贵都大饭店办公楼405单元

Phone: +86-21-62489820

Fax: +86-21-62489821 
(C) 2011 The Author(s). Licensee IntechOpen. This chapter is distributed under the terms of the Creative Commons Attribution-NonCommercialShareAlike-3.0 License, which permits use, distribution and reproduction for non-commercial purposes, provided the original is properly cited and derivative works building on this content are distributed under the same license. 